Check for updates

Cite this: RSC Adv., 2017, 7, 54235

Received 9th October 2017

Accepted 21st November 2017

DOI: 10.1039/c7ra11104e

rsc.li/rsc-advances

\section{Control of the molecular packing of chloroboron(III) and fluoroboron(III) subnaphthalocyanines by designing peripheral substituents $\dagger$}

\begin{abstract}
Akuto Takagi and Tadashi Mizutani (D) *
Chloroboron(III) and fluoroboron(III) hexa(1-alkynyl)- and hexa(2-arylethynyl)subnaphthalocyanines with a large dipole moment were prepared by Sonogashira coupling of hexaiodosubnaphthalocyanines with substituted acetylenes. Introduction of butyl or longer alkyl groups via ethynylene linkages on the periphery resulted in lower melting points and higher solubility in dichloromethane. X-ray diffraction (XRD) patterns of the cast film indicated that hexa(2-(4-hexylphenyl)ethynyl)- and hexa(2-(4hexyloxyphenyl)ethynyl)subnaphthalocyanines with a B-F bond are packed in a discotic hexagonal columnar phase with lattice constants $a=59-64 \AA$ and stacking distance $c=4.7-4.8 \AA$. The $Q$-band in visible spectra of the thin film of these $\mathrm{B}-\mathrm{F}$ derivatives was blue-shifted, supporting the formation of $\mathrm{H}$ aggregate in stacked columns. Polarized optical microscopy showed that these subnaphthalocyanines with a B-F bond exhibited a mesophase at $180{ }^{\circ} \mathrm{C}$. XRD of these subnaphthalocyanines at $180{ }^{\circ} \mathrm{C}$ confirms a two dimensional hexagonal phase. XRD of the corresponding derivatives with a $\mathrm{B}-\mathrm{Cl}$ bond showed that they were either amorphous or less crystalline. We suggest that the fluorine atom in the B-F group can fit into the cleft of cone-shaped subnaphthalocyanine, owing to the smaller van der Waals radius of $\mathrm{F}$ than $\mathrm{Cl}$, to stabilize the columnar packing structure.
\end{abstract}

\section{Introduction}

Cyclic oligopyrroles such as porphyrins and phthalocyanines are important dyes whose optical, redox, and semi-conductive properties have been employed in active materials for diverse optoelectric systems, such as photosynthesis, solar cells, ${ }^{1}$ and electroluminescence devices. ${ }^{2}$ Much effort has been directed toward the control of the molecular packing of these dyes, ${ }^{3}$ which would affect the electrical conductivity of their films. ${ }^{4}$ Charge carrier mobilities of phthalocyanines with eight alkoxy groups were reported to be dependent on the molecular packing, i.e., crystalline, mesoscopic and isotropic phases. ${ }^{5}$ Among cyclic oligopyrroles, subphthalocyanines have a unique cone shape, ${ }^{6}$ and $\pi$-conjugation occurs on the cone-shaped framework. ${ }^{7}$ Verreet $e t$ al. ${ }^{8}$ reported that subnaphthalocyanine showed better energy conversion efficiency than subphthalocyanine in an organic solar cell combined with $\mathrm{C}_{60}$ due to the red shifted absorption. Subnaphthalocyanine with a larger core size than subphthalocyanine also has advantages as a semi-conductive material since Warman et al. ${ }^{9}$ reported

Department of Molecular Chemistry and Biochemistry, Faculty of Science and Engineering, Doshisha University, Kyotanabe, Kyoto, 610-0321 Japan. E-mail: tmizutan@mail.doshisha.ac.jp

$\dagger$ Electronic supplementary information (ESI) available. See DOI: 10.1039/c7ra11104e that the charge mobilities increase with increasing core sizes of the discotic molecules. In addition to the visible light absorption, redox properties, and semi-conductive properties, subphthalocyanines and subnaphthalocyanines have a large dipole moment nearly perpendicular to the $\pi$-conjugated electronic systems. Therefore, control of molecular packing would lead to unique dielectric functions that other cyclic oligo tetrapyrroles cannot exhibit. There have been several studies on the control of assembly of subphthalocyanines. Torres and co-workers reported that subphthalocyanines with nine dodecyloxy groups showed a liquid-crystalline phase which shows permanent polarization in the presence of electric fields. ${ }^{10}$

We have reported synthesis of subnaphthalocyanines with six halogen atoms on the naphthalene rings to tune the HOMO/ LUMO energy levels as an active layer of photovoltaic cells. ${ }^{12}$ Compared to subphthalocyanine, subnaphthalocyanine has a smaller HOMO-LUMO gap, and adsorbs visible light in the 600-700 nm range. Halogenation of subnaphthalocyanine resulted in a better orbital energy matching with fullerenes or fluorosubphthalocyanines at the $\mathrm{p}-\mathrm{n}$ junction. ${ }^{11}$ Introduction of six halogens in the periphery of subnaphthalocyanines cancelled the original dipole moment of subnaphthalocyanines because the dipole moment of a $\mathrm{B}-\mathrm{Cl}$ bond and the combined dipole moment of $\mathrm{C}$-halogen bonds are anti-parallel. As shown in Table 1, dipole moments of subnaphthalocyanines increases 
Table 1 Dipole moments of chloroboron(III) and fluoroboron(III) subnaphthalocyanines calculated with ab initio molecular orbital theory. ${ }^{a}$ See Chart 1 for the structures

\begin{tabular}{lll}
\hline & \multicolumn{2}{c}{ Dipole moment $/ D$} \\
\cline { 2 - 3 } Peripheral substituent (R) & $\mathrm{X}=\mathrm{Cl}$ & $\mathrm{X}=\mathrm{F}$ \\
\hline $\mathrm{Cl}$ & 1.51 & 0.22 \\
$\mathrm{~F}$ & 2.61 & 1.08 \\
$\mathrm{I}$ & 3.78 & 2.76 \\
$\mathrm{H}$ & 5.24 & 3.91 \\
$\mathrm{PhC} \equiv \mathrm{C}-$ & 6.32 & 4.88 \\
${ }^{a} \mathrm{~B} 3 \mathrm{LYP} / \mathrm{LAN2DZ}$ for $\mathrm{R}=\mathrm{I}, \mathrm{B} 3 \mathrm{LYP} / 6-31 \mathrm{G}(\mathrm{D})$ for others. &
\end{tabular}

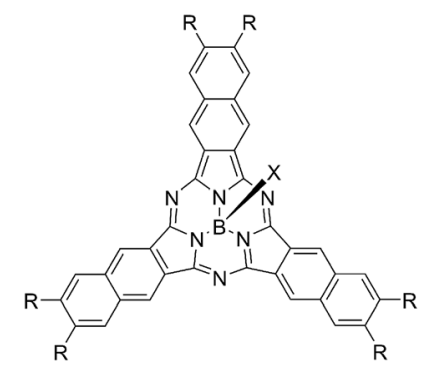

Chart 1 Structures of subnaphthalocyanines.

as the peripheral substituents are $\mathrm{Cl}<\mathrm{F}<\mathrm{I}<\mathrm{H}<2$-phenylethynyl. Therefore, substitution of alkynyl groups on the naphthalene rings is an attractive strategy to obtain highly dipolar subnaphthalocyanines. The $\mathrm{B}-\mathrm{Cl}$ derivatives showed a larger dipole moment than the $\mathrm{B}-\mathrm{F}$ derivatives, but the $\mathrm{B}-\mathrm{Cl}$ derivatives are more labile than the $\mathrm{B}-\mathrm{F}$ derivatives. In this paper we report that hexaiodosubnaphthalocyanines were converted to hexa(1-alkynyl)subnaphthalocyanines and hexa(2arylethynyl)subnaphthalocyanines, and changes in the peripheral substituents as well as the axial ligand from $\mathrm{Cl}$ to $\mathrm{F}$ can effectively control the molecular packing of these subnaphthalocyanine derivatives.

\section{Results and discussion}

Synthesis of chloroboron(III) and fluoroboron(III) hexa(1alkynyl)subnaphthalocyanines and hexa(2-arylethynyl) subnaphthalocyanines

Chart 2 shows structures of subnaphthalocyanines studied in this paper. Synthetic routes to chloroboron(III) subnaphthalocyanines 1a-f and fluoroboron(III) subnaphthalocyanines $\mathbf{2 a - g}$ are shown in Scheme 1. Chloroboron(III) 3,4,12,13,21,22hexaiodosubnaphthalocyanine was prepared according to the literature. ${ }^{12,13}$ Bender and coworkers reported that cyclotrimerization of unsubstituted 2,3-naphthalenedicarbonitrile in the presence of $\mathrm{BCl}_{3}$ gave by-products with naphthalene rings chlorinated, ${ }^{\mathbf{1 4}}$ while cyclotrimerization of 6,7-diiodo-2,3naphthalenedicarbonitrile $\mathbf{1 1}$ did not give any chlorinated byproducts owing to the inactivation of naphthalene ring toward electrophilic substitution by iodine groups. Therefore, isolation

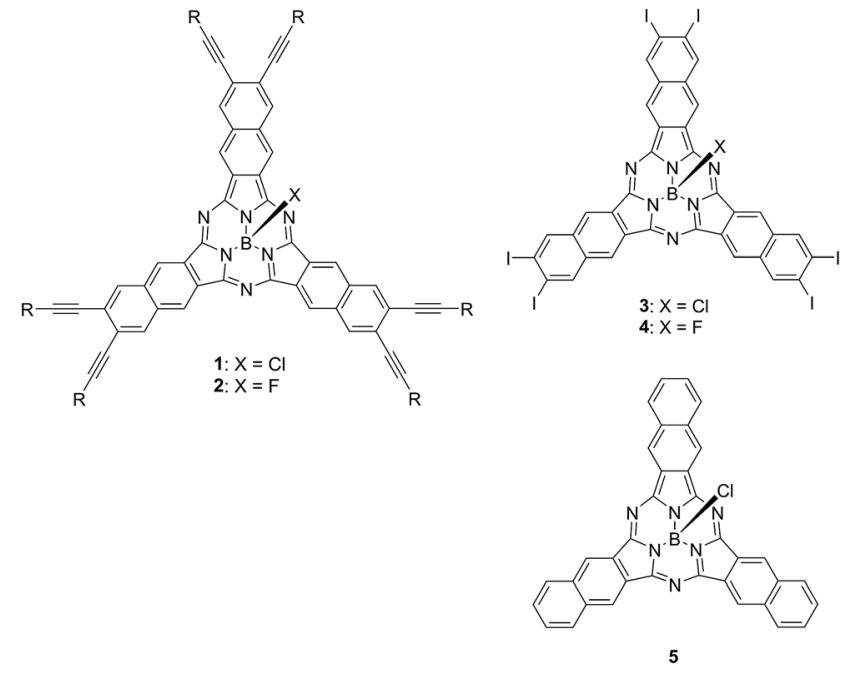

Chart 2 Structures of subnaphthalocyanines 1-5.

of 3 was facile. Sonogashira coupling was employed to substitute iodines of hexaiodosubnaphthalocyanine $\mathbf{3}$ with alkynyl groups. ${ }^{15} \mathrm{~B}-\mathrm{Cl}$ derivatives $\mathbf{1 a - f}$ were isolated with silica gel column chromatography eluted with toluene.

Substitution of axial $\mathrm{Cl}$ with $\mathrm{F}$ by Torres's procedure ${ }^{\mathbf{1 6}}$ gave fluoroboron(III) 3,4,12,13,21,22-hexaiodosubnaphthalocyanine 4. B-F derivatives $\mathbf{2 a - 9}$ were prepared similarly from fluoroboron(III) hexaiodosubnaphthalocyanine $\mathbf{4}$ by Sonogashira coupling, and isolated using silica gel column chromatography, except for 2c. For 2c, owing to low solubility in organic solvents, the product was crystallized by adding hexane to the reaction mixture, and the crystal was washed with organic solvents, and dried in vacuo. The precursor 15, a coupling component for $\mathbf{2 g}$, was prepared according to the literature (Scheme 2). ${ }^{17}$ These subnaphthalocyanines were identified by ${ }^{1} \mathrm{H}$ NMR, ${ }^{13} \mathrm{C}$ NMR,
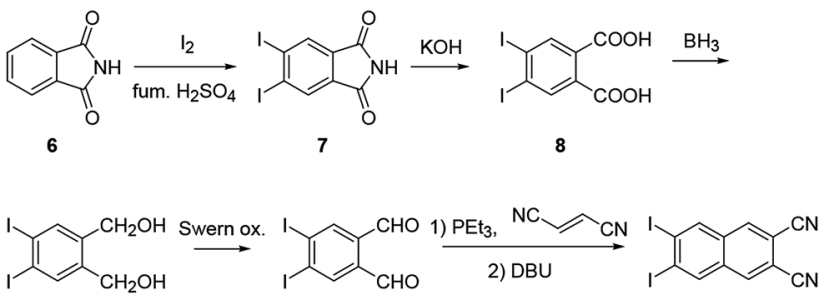

9

10

11

$\stackrel{\mathrm{BCl}_{3}}{\longrightarrow} 3 \stackrel{\mathrm{AgBF}_{4}}{\longrightarrow} 4 \frac{\mathrm{Pd}(0), \mathrm{Cul}}{\mathrm{Et}_{3} \mathrm{~N}, \equiv \mathrm{R}} 2 \mathrm{a}-\mathrm{g}$

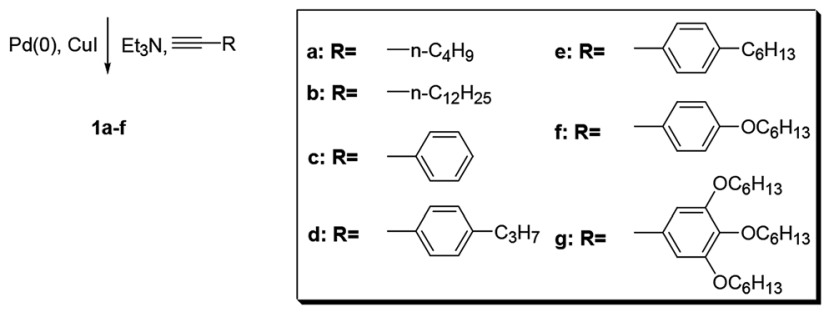

Scheme 1 Synthesis of substituted subnaphthalocyanines 1 and 2 . 


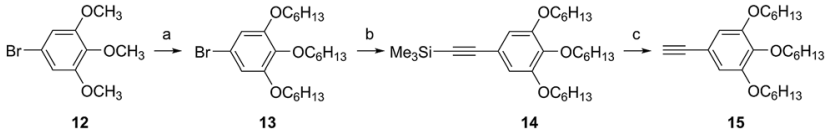

Scheme 2 Synthesis of arylethyne 15. Reagents and conditions. (a) $\mathrm{BBr}_{3} ; \mathrm{C}_{6} \mathrm{H}_{13} \mathrm{Br}, \mathrm{K}_{2} \mathrm{CO}_{3}, 65 \%$; (b) trimethylsilylacetylene, $\mathrm{Pd}\left(\mathrm{PPh}_{3}\right)_{4}-\mathrm{Cul}$, piperidine, $80{ }^{\circ} \mathrm{C}, 98 \%$; (c) $\mathrm{K}_{2} \mathrm{CO}_{3}, \mathrm{DCM} / \mathrm{MeOH}, 86 \%$.

MALDI-TOF mass spectroscopy, high resolution FAB mass spectroscopy and UV-visible spectroscopy. Their purities were checked by gel-permeation HPLC, which clearly detected the presence of penta- or tetrasubstituted by-products before silica gel column purification. Isolated yields of Sonogashira coupling are listed in Table 2 . The yields of Sonogashira coupling were 3$8 \%$ for $\mathrm{B}-\mathrm{Cl}$ derivatives 1 , while they were $10-27 \%$ for $\mathrm{B}-\mathrm{F}$ derivatives 2 . Lower yields of $\mathrm{B}-\mathrm{Cl}$ derivatives 1 can be ascribed to the labile $\mathrm{B}-\mathrm{Cl}$ bond. The $\mathrm{B}-\mathrm{F}$ derivatives 2 were also prepared from the $\mathrm{B}-\mathrm{Cl}$ derivatives $\mathbf{1}$ by substitution of $\mathrm{Cl}$ with $\mathrm{F}$, but the overall yields were lower in this route, due to the labile B-Cl bond.

\section{Solubilities and melting points}

Solubilities and melting points of subnaphthalocyanines 1a-f and $\mathbf{2 a}-\mathbf{g}$ are listed in Table 3 . Solubilities were determined by measuring the absorbances of saturated solutions with UVvisible spectrophotometry. The molar extinction coefficients at the Q-band peak were determined using $2 \times 10^{-6} \mathrm{M} \mathrm{CH}_{2} \mathrm{Cl}_{2}$ solutions. Compared to unsubstituted chloroboron(III) subnaphthalocyanine 5, 1a-f were 40 to 310 times more soluble in $\mathrm{CH}_{2} \mathrm{Cl}_{2}$. Solubilities increased with longer alkyl groups for homologs 1a/1b and 1c/1d/1e. By substitution of axial $\mathrm{Cl}$ with $\mathrm{F}$, solubilities were much lower, showing that a smaller fluorine atom would stabilize molecular packing in the solid state. This observation is contrary to the previous report that fluoroboron(III) subphthalocyanine showed higher solubility than chloroboron(III) subphthalocyanine and bromoboron(III) subphthalocyanine. ${ }^{18}$ Melting points of 1-alkynyl derivatives 2a and $2 \mathrm{~b}$ were lower than $120^{\circ} \mathrm{C}$, while those of 2-phenylethynyl and 2-(4-propylphenyl)ethynyl derivative (2c and 2d) were higher than $375{ }^{\circ} \mathrm{C}$. Thus, melting points were lowered by introduction of alkyl groups in the periphery, and raised by introduction of phenyl groups. Polarized optical microscope (POM) observation under cross-Nicole conditions displayed that

Table 2 Yields of Sonogashira coupling to afford subnaphthalocyanines $1 \mathrm{a}-\mathrm{f}$ and $2 \mathrm{a}-\mathrm{g}$

\begin{tabular}{llll}
\hline & Yield (\%) & Yield (\%) \\
\hline 1a & 7 & 2a & 19 \\
1b & 6 & 2b & 16 \\
1c & 8 & $\mathbf{2 c}$ & 10 \\
1d & 8 & $\mathbf{2 d}$ & 20 \\
1e & 6 & $\mathbf{2 e}$ & 22 \\
1f & 3 & $\mathbf{2 f}$ & 27 \\
& & $\mathbf{2 g}$ & 10
\end{tabular}

Table 3 Solubilities of subnaphthalocyanines $1 \mathrm{a}-\mathrm{f}, 2 \mathrm{a}-\mathrm{g}$ and 5 in dichloromethane at $25{ }^{\circ} \mathrm{C}$ and melting points or glass transition temperatures

\begin{tabular}{lll}
\hline & & $\begin{array}{l}\text { Melting point or } \\
\text { glass transition temperature }\left({ }^{\circ} \mathrm{C}\right)\end{array}$ \\
\hline $\mathbf{1 a}$ & 5.02 & $77-80^{a}$ \\
$\mathbf{1 b}$ & 9.37 & $70-73^{a}$ \\
$\mathbf{1 c}$ & 1.19 & $>375$ \\
$\mathbf{1 d}$ & 1.52 & $>375$ \\
$\mathbf{1 e}$ & 2.13 & $102-108^{a}$ \\
$\mathbf{1 f}$ & 3.70 & $98-106^{a}$ \\
$\mathbf{2 a}$ & 1.35 & $114-118$ \\
$\mathbf{2 b}$ & 2.30 & $100-105$ \\
$\mathbf{2 c}$ & $6.48 \times 10^{-4}$ & $>375$ \\
$\mathbf{2 d}$ & 0.90 & $>375$ \\
$\mathbf{2 e}$ & 1.62 & $170-178$ \\
$\mathbf{2 f}$ & 2.01 & $168-176$ \\
$\mathbf{2 g}$ & 10.62 & $80-86^{a}$ \\
$\mathbf{5}$ & 0.03 & $270-276$ \\
${ }^{a}$ & &
\end{tabular}

the thin film of chloroboron(III) derivatives 1a-f were optically isotropic in the solid state, indicating that these are in a glassy state. Therefore, the temperatures reported for 1a-f listed in Table 3 are glass transition temperatures. For fluoroboron(III) derivatives $2 \mathbf{2}-\mathbf{f}$, the thin film was crystalline, as confirmed by the bright image observed with a POM under cross-Nicole conditions. The thin film of $\mathbf{2} \mathbf{g}$ was not crystalline as judged by POM observations.

\section{UV-visible spectra in solutions and of cast films}

Chloroboron(III) subnaphthalocyanine $\mathbf{5}$ in toluene shows a strong absorption at $660 \mathrm{~nm}$ and an absorption at $299 \mathrm{~nm}$ in the near UV with almost equal absorbances. ${ }^{19}$ The former band is called a Q-band, and the latter band is called a B-band or a Soret band. Fig. 1 shows UV-visible spectra of $\mathrm{B}-\mathrm{Cl}$ derivatives 1 in $\mathrm{CH}_{2} \mathrm{Cl}_{2}$. The absorption maxima in the Q-band were shifted to the longer wavelength in the order: $\mathbf{5}(\mathrm{H})<\mathbf{1 a}, \mathbf{b}(1$-alkynyl) $<$ 1c-f (2-arylethynyl). The molar absorption coefficients of 1a-f

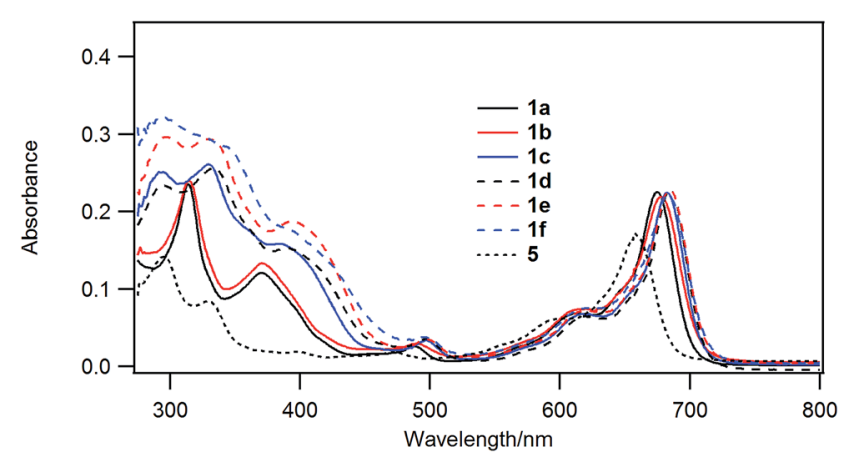

Fig. 1 UV-visible spectra of 1a (black solid line), 1b (red solid line), 1c (blue solid line), 1d (black dashed line), 1e (red dashed line), and 1f (blue dashed line) and the parent chloroboron(III) subnaphthalocyanine 5 (black dotted line). The concentration was $2 \times 10^{-6} \mathrm{M}$ in dichloromethane. 


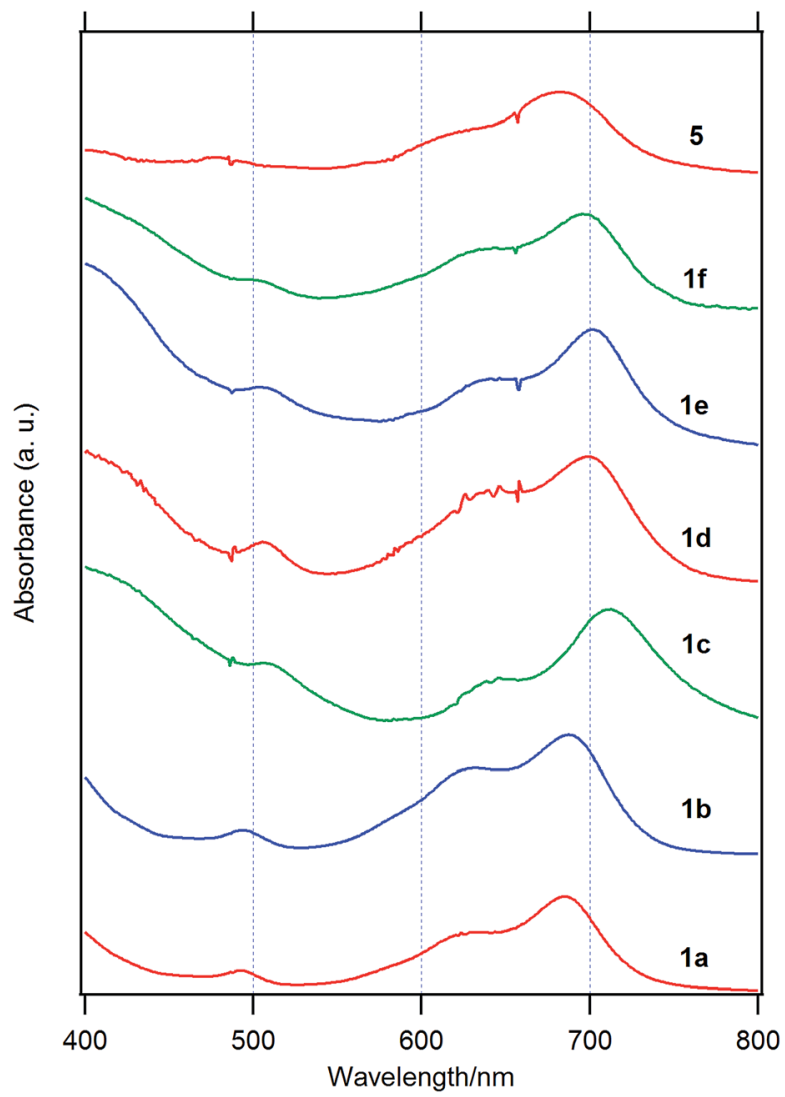

Fig. 2 Visible spectra of $1 \mathrm{a}, 1 \mathrm{~b}, 1 \mathrm{c}, 1 \mathrm{~d}, 1 \mathrm{e}$, and $1 \mathrm{f}$ and the parent chloroboron(III) subnaphthalocyanine 5 on silicate glass.

were larger than that of the parent 5 . The substituent effects are more obvious in the B-band in the $300-500 \mathrm{~nm}$ region: $1 \mathrm{a}$ and 1b with 1-alkynyl groups showed peaks at 318 and $369 \mathrm{~nm}$, while 1c-f with 2-arylethynyl groups showed a more intense absorption in the B-band. Fig. 2 shows the visible spectra of B$\mathrm{Cl}$ derivatives of the cast film on silicate glass. A solution of $\mathbf{1}$ in dichloromethane was dropped on silicate glass, and the film was kept at room temperature in Ar for 2 days. The absorption maxima in the Q-band were shifted to the longer wavelength in the order: $\mathbf{5}(\mathrm{H})<\mathbf{1 a}, \mathbf{1 b}$ (1-alkynyl) < 1d-f (4-alkyl or 4-alkoxyphenylethynyl) < 1c (phenyl).

Table 4 Absorption maxima in the $Q$-band of $1 a-f$ and reference subnaphthalocyanine 5 in dichloromethane, on silicate glass, and these shift

\begin{tabular}{llll}
\hline & $\lambda_{\text {abs }}(\mathrm{nm})$ & & \\
\cline { 2 - 4 } & In $\mathrm{CH}_{2} \mathrm{Cl}_{2}$ & On silicate glass & Shift \\
\hline 1a & 675 & 685 & 10 \\
1b & 678 & 687 & 9 \\
1c & 682 & 712 & 30 \\
1d & 685 & 698 & 13 \\
1e & 685 & 703 & 18 \\
1f & 683 & 696 & 13 \\
5 & 658 & 680 & 22
\end{tabular}

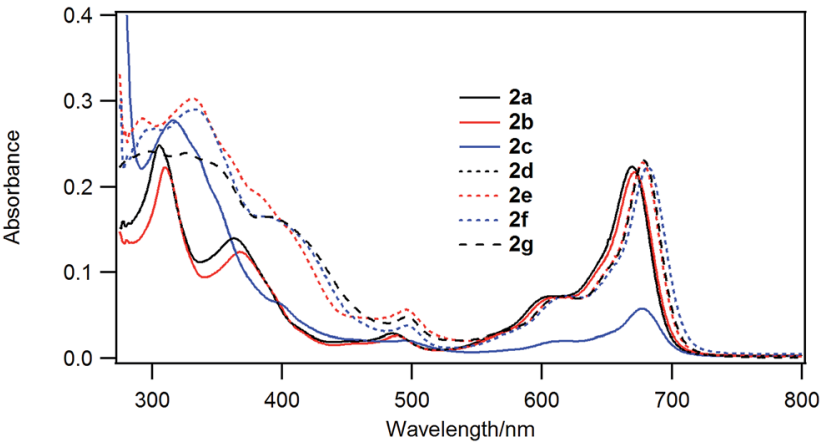

Fig. 3 UV-visible spectra of $2 a$ (black solid line), $2 \mathrm{~b}$ (red solid line), $2 \mathrm{c}$ (blue solid line), 2d (black dotted line), $2 \mathrm{e}$ (red dotted line), $2 \mathrm{f}$ (blue dotted line), and $2 \mathrm{~g}$ (black dashed line). The concentration of $2 \mathrm{a}, 2 \mathrm{~b}$ and $2 \mathrm{~d}-\mathrm{g}$ was $2 \times 10^{-6} \mathrm{M}$ in dichloromethane. Visible spectra of $2 \mathrm{c}$ was the spectra of saturated dichloromethane solution.

In Table 4 are listed the absorption maxima in solution and of the cast film. The shifts of the Q-band of $\mathrm{B}-\mathrm{Cl}$ derivatives of the cast film to the longer wavelength compared to that in solutions indicate that J-aggregate forms in the cast film. The displacements are 9-30 $\mathrm{nm}$, and increased in the order: $\mathbf{1 a}, \mathbf{1 b}$ (alkyl) < 1d-f (alkylphenyl or alkoxyphenyl) $<5(\mathrm{H})<\mathbf{1 c}$ (phenyl).

Fig. 3 shows the UV-visible spectra of the B-F derivatives 2 in $\mathrm{CH}_{2} \mathrm{Cl}_{2}$. The absorption maxima were shifted to the longer wavelength in the order: $2 \mathbf{a}, \mathbf{b}$ (alkyl) $<\mathbf{2 c - f}$ (phenyl) in $\mathrm{CH}_{2} \mathrm{Cl}_{2}$.

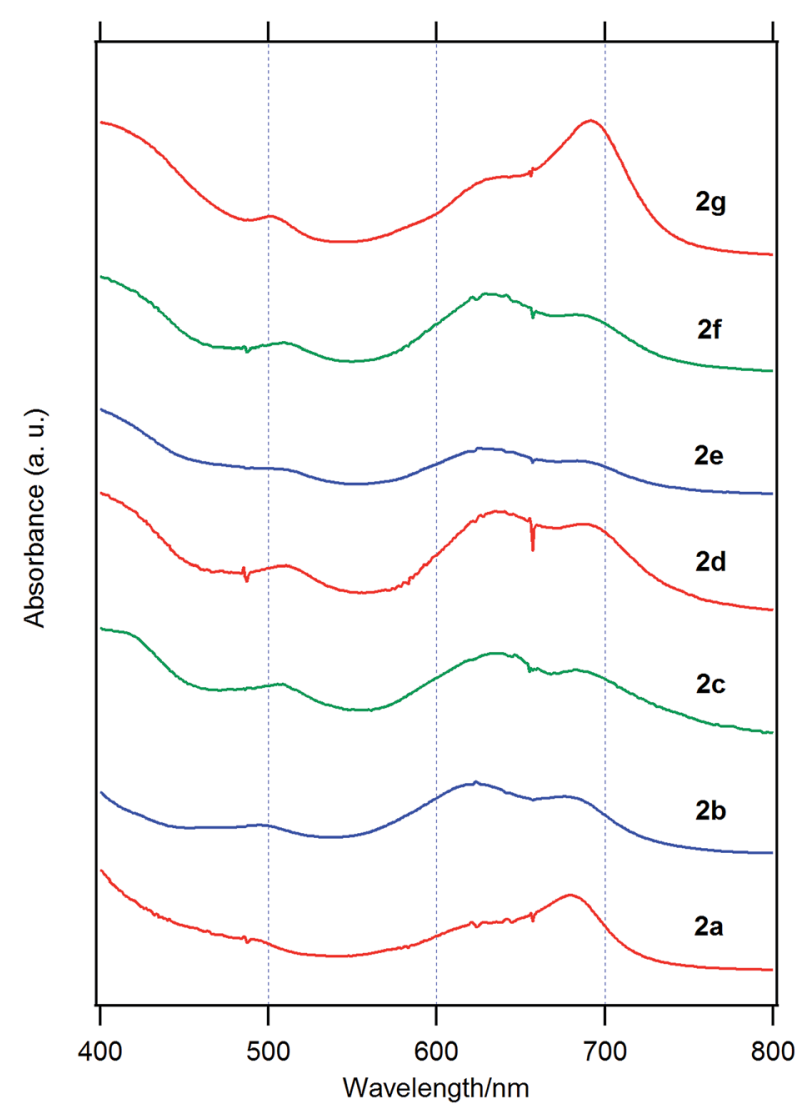

Fig. 4 Visible spectra of $2 \mathrm{a}, 2 \mathrm{~b}, 2 \mathrm{c}, 2 \mathrm{~d}, 2 \mathrm{e}, 2 \mathrm{f}$, and $2 \mathrm{~g}$ on silicate glass. 
Table 5 Absorption maxima in the $\mathrm{Q}$-band of $2 \mathrm{a}-\mathrm{g}$ in $\mathrm{CH}_{2} \mathrm{Cl}_{2}$, on silicate glass, and these shift

\begin{tabular}{llll}
\hline & $\lambda_{\text {abs }}(\mathrm{nm})$ & & \\
\cline { 3 - 4 } & & $\begin{array}{l}\text { On silicate } \\
\text { glass }\end{array}$ & Shift \\
\hline In $\mathrm{CH}_{2} \mathrm{Cl}_{2}$ & 679 & 10 \\
2b & 669 & 624 & -47 \\
2c & 671 & 632 & -45 \\
2d & 677 & 642 & -36 \\
2e & 678 & 625 & -53 \\
2f & 678 & 629 & -52 \\
2g & 681 & 692 & 14 \\
\hline
\end{tabular}

The B-band was also affected by substituents in a similar way as the $\mathrm{B}-\mathrm{Cl}$ derivatives. The molar absorption coefficients of all of alkynyl substituted derivatives were similar. Fig. 4 shows visible spectra of B-F derivatives 2 of the cast film on silicate glass. Solutions of $\mathbf{2 a - b}$ and $\mathbf{2} \mathbf{d}-\mathbf{g}$ in dichloromethane and $\mathbf{2 c}$ in pyridine were dropped on silicate glass, the solvent was evaporated, and the resulting film was kept in Ar for 2 days before recording visible spectra. The spectra were almost identical with those of as-prepared film. In Table 5 are listed the absorption maxima in solution and of the cast film. It is noteworthy that the Q-band absorption envelope of $\mathbf{2} \mathbf{b}-\mathbf{f}$ is different from that in $\mathrm{CH}_{2} \mathrm{Cl}_{2}$, that of 1 in $\mathrm{CH}_{2} \mathrm{Cl}_{2}$, and that of 1 of the cast film. The Qband of $\mathbf{2} \mathbf{b}-\mathbf{f}$ of the cast film exhibited larger absorption in the 600-650 $\mathrm{nm}$ range than the absorption band in the 650-700 $\mathrm{nm}$ range. The shifts to the shorter wavelength indicate that $2 \mathbf{b}-\mathbf{f}$ form $\mathrm{H}$-aggregate in the cast film. ${ }^{20}$ Phthalocyanines with oligo(ethylene oxide) units showed a blue-shifted Q-band, and it was ascribed to formation of $\mathrm{H}$-aggregate. ${ }^{21}$ The Q-band spectral shapes are similar to those reported for $\mu$-oxo dimers of iron phthalocyanines ${ }^{22,23}$ and subphthalocyanines, ${ }^{24}$ supporting the formation of a stacked dimer or a stacked column in the cast film. In contrast, the Q-band of $2 \mathbf{a}$ and $2 \mathbf{g}$ of the cast film was similar to those observed for $\mathrm{B}-\mathrm{Cl}$ derivatives 1 : 10-14 nm red-

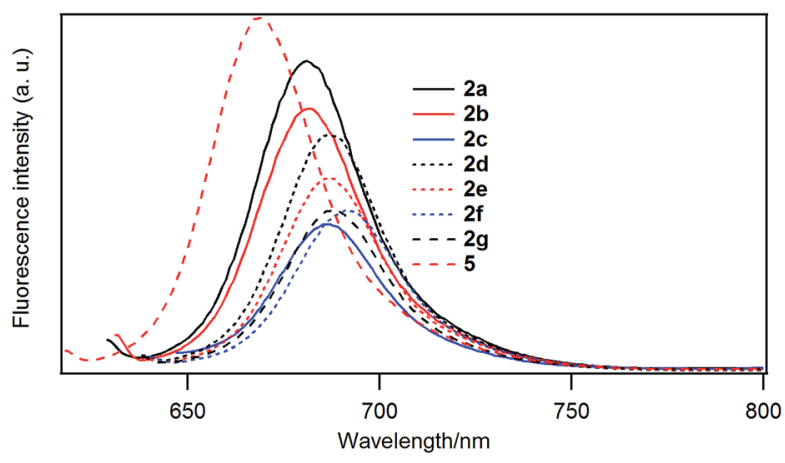

Fig. 5 Fluorescence spectra of $2 a$ (black solid line), $2 b$ (red solid line), 2c (blue solid line), 2d (black dotted line), 2e (red dotted line), $2 f$ (blue dotted line), and $2 \mathrm{~g}$ (black dashed line), and 5 (red dashed line) at $298 \mathrm{~K}$ in dichloromethane where the samples were excited at $\left(\lambda_{\max }\right.$ abs 50) $\mathrm{nm}$. Each sample has absorbance of 0.02 at the excitation wavelength.
Table 6 Absorption and emission maxima, and fluorescence quantum yields of $2 \mathrm{a}-\mathrm{g}$ and reference subnaphthalocyanine 5 in $\mathrm{CH}_{2} \mathrm{Cl}_{2}$

\begin{tabular}{|c|c|c|c|c|}
\hline & $\lambda_{\mathrm{abs}} / \mathrm{nm}$ & $\lambda_{\mathrm{em}} / \mathrm{nm}$ & $\begin{array}{l}\text { Stokes shift } \\
(\mathrm{nm})\end{array}$ & $\begin{array}{l}\text { Fluorescence } \\
\text { quantum yield }\end{array}$ \\
\hline $2 a$ & 669 & 681 & 12 & 0.19 \\
\hline $2 b$ & 671 & 682 & 11 & 0.16 \\
\hline $2 c$ & 677 & 687 & 10 & 0.09 \\
\hline $2 d$ & 678 & 687 & 9 & 0.14 \\
\hline $2 e$ & 678 & 686 & 8 & 0.11 \\
\hline $2 f$ & 680 & 691 & 11 & 0.10 \\
\hline $2 g$ & 678 & 688 & 10 & 0.10 \\
\hline 5 & 658 & 669 & 11 & 0.22 \\
\hline
\end{tabular}

shift relative to the peak maximum in solution indicated that $2 \mathbf{a}$ and $2 \mathrm{~g}$ do not form $\mathrm{H}$-aggregate in the cast film.

\section{Fluorescence spectra}

Fig. 5 shows the fluorescence emission spectra of the B-F derivatives in $\mathrm{CH}_{2} \mathrm{Cl}_{2}$. In Table 6 are listed the emission maxima, Stokes shifts, and fluorescence quantum yields. The fluorescence quantum yields were determined based on the reported quantum yield of unsubstituted derivative $5(0.22){ }^{25}$ The fluorescence quantum yields decreased in the order: $5(\mathrm{H})>$ $2 \mathbf{a}\left(-\mathrm{C}_{4} \mathrm{H}_{9}\right)>2 \mathbf{b}\left(-\mathrm{C}_{12} \mathrm{H}_{25}\right)>2 \mathbf{d}\left(-\mathrm{PhC}_{3} \mathrm{H}_{7}\right)>2 \mathbf{e}\left(-\mathrm{PhC}_{6} \mathrm{H}_{13}\right)>2$ f $\left(-\mathrm{PhOC}_{6} \mathrm{H}_{13}\right), 2 \mathrm{~g}\left(-\mathrm{Ph}\left(\mathrm{OC}_{6} \mathrm{H}_{13}\right)_{3}\right)>2 \mathrm{c}(-\mathrm{Ph})$.

Fluorescence emission spectra of $2 \mathbf{b}, 2 \mathbf{d}, 2 \mathbf{e}$ and $2 \mathrm{f}$ in $\mathrm{CH}_{2}$ $\mathrm{Cl}_{2}$ : DMSO (1:1, v/v) are shown in Fig. S51. $\dagger$ In addition to the emission band peaked at 685-689 $\mathrm{nm}, \mathbf{2 b}$ and $2 \mathrm{e}$ exhibited a new band around $800 \mathrm{~nm}$. Excitation spectra for the new band are shown in Fig. S52 and S53, $\dagger$ and they were similar to the UVvisible spectra of the thin film shown in Fig. 4 . Therefore, $\mathbf{2 b}$ and 2e form $\mathrm{H}$-aggregate in $\mathrm{CH}_{2} \mathrm{Cl}_{2}-\mathrm{DMSO}$ (1:1), whose structures are similar to those formed in the cast film.

\section{Polarized optical microscope}

Fig. 6 shows the polarized optical microscopic images of the cast film of $2 \mathrm{e}$ and $2 \mathrm{f}$ under crossed-Nicols conditions at $180{ }^{\circ} \mathrm{C}$ above the melting point. The film was sandwiched between two glasses and the glasses were pressed above the melting point. These images clearly showed that these films are optically anisotropic above the melting point. We also attempted to
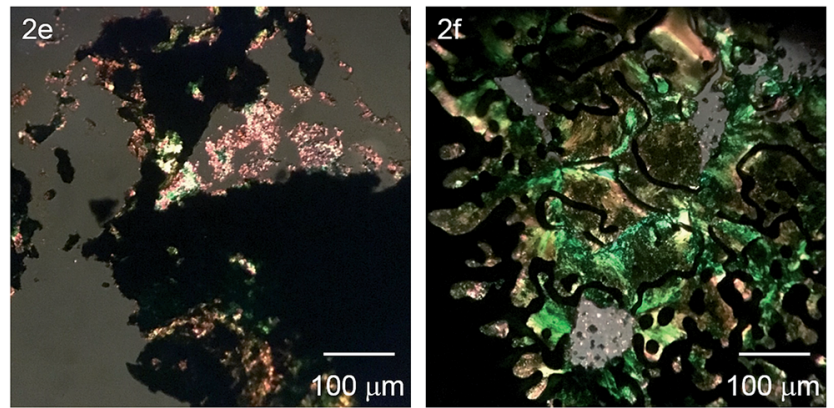

Fig. 6 POM microphotographs of $2 \mathrm{e}$ and $2 \mathrm{f}$ at $180^{\circ} \mathrm{C}$ under crossedNicols conditions. 

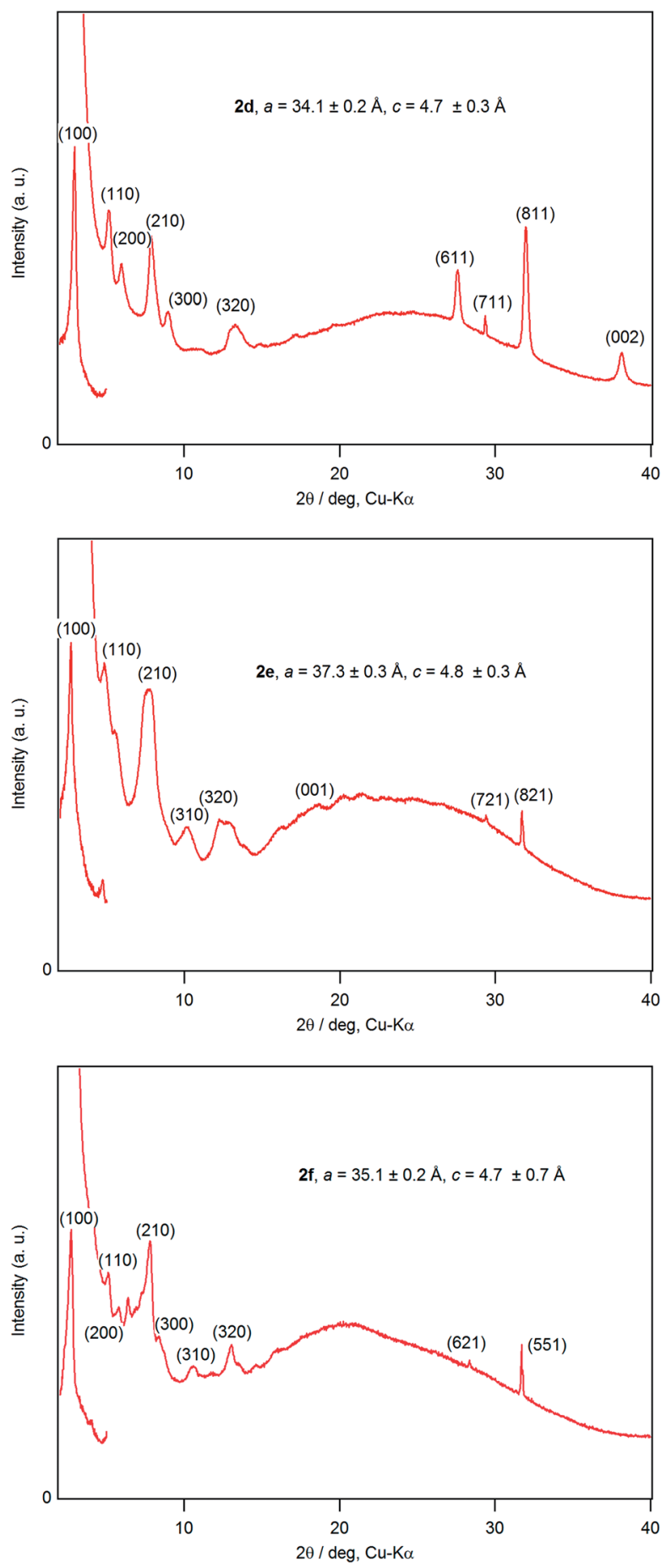

Fig. 7 Powder $\mathrm{X}$-ray diffraction patterns of $2 \mathrm{~d}-\mathrm{f}$. Lattice constants, $a$ and $c$, were determined by least-squares fitting based on the hexagonal lattice: $\frac{1}{d}=\sqrt{\frac{4}{3} \frac{h^{2}+h k+k^{2}}{a^{2}}+\frac{l^{2}}{c^{2}}}$. While the XRD patterns were recorded with a $1 \mathrm{D}$ silicon strip detector for a wide angle region, $2 \theta>3^{\circ}$, they were recorded with a OD detector for the low angle region, $2 \theta=2-5^{\circ}$.

detect phase transition by differential scanning calorimetry, while no clear enthalpy changes were observed. Slow kinetics due to highly viscous nature and/or low degree of crystallinity may be responsible for the lack of DSC peaks. Serrano and
Table 7 Powder X-ray diffraction peaks of $2 d, d$-spacings, and Miller indices $(h k l)$ based on the hexagonal lattice with $a=34.1 \pm 0.2 \AA$ and $c$ $=4.7 \pm 0.3 \AA$

\begin{tabular}{lrllll}
\hline $2 \theta(\mathrm{deg})$ & $d(\AA)$ & $(h k l)$ & $2 \theta(\mathrm{deg})$ & $d(\AA)$ & $(h k l)$ \\
\hline 2.95 & 29.88 & $(100)$ & 13.19 & 6.71 & $(320)$ \\
5.32 & 16.59 & $(110)$ & 27.54 & 3.24 & $(611)$ \\
6.08 & 14.52 & $(200)$ & 29.34 & 3.04 & $(711)$ \\
7.84 & 11.27 & $(210)$ & 31.93 & 2.80 & $(811)$ \\
8.95 & 9.87 & $(300)$ & 38.10 & 2.36 & $(002)$
\end{tabular}

coworkers reported that no DSC peak was observed for the liquid crystalline porphyrin derivatives. ${ }^{26}$

\section{Powder X-ray diffraction}

A dichloromethane solution of $\mathbf{2 d}, \mathbf{2 e}$, and $2 \mathbf{f}$ was dropped on silicate glass, and the glass plate was dried at room temperature for 2 weeks in dark in Ar to allow crystallization. A thin film of $\mathbf{2 d}$, 2e, and 2 f prepared in this way was subjected to powder X-ray diffraction studies (Fig. 7). All films showed a diffraction peak in the low angle region around $2 \theta$ of $2.8^{\circ}$, showing a long distance periodicity. The diffraction peaks were indexed based on a twodimensional hexagonal lattice as shown in Tables 7-9. The hexagonal lattice parameter $a$ ranged from 34.1 to $37.3 \AA$ A. We also assigned some of the peaks to the stacking distance along the $c$ direction. It should be noted that the peaks originating from the stacking distance at $2 \theta=29.45^{\circ}$ and $31.69^{\circ}$ for $2 \mathrm{e}$ as well as the peaks at $28.34^{\circ}$ and $31.70^{\circ}$ for $2 \mathrm{f}$ were not observed for the asprepared cast film before aging. This observation suggests that the hexagonal column are formed quickly, while the periodic stacking of the cone-shaped molecules occurs slowly. The lattice constant $c$ ranged from 4.7 to $4.8 \AA$. These X-ray diffraction studies confirm the hexagonal columnar structure of fluoroboron(III) subnaphthalocyanines bearing 2-(4-alkylphenyl)ethynyl groups in the cast film. In contrast to the $\mathrm{B}-\mathrm{F}$ derivatives, XRD of $\mathrm{B}-\mathrm{Cl}$ derivatives $\mathbf{1 d}, \mathbf{1 e}$, and $\mathbf{1 f}$ indicates that they are poorly crystalline (see Fig. S78-S80 in ESI $\dagger$ ). Clays, Kim and coworkers ${ }^{27}$ reported that hexakis(hexadecylthio)subphthalocyanine exhibited hexagonal columnar mesophase with a lattice constant $a=33.02 \AA$. The molecular size of this compound is similar to $2 \mathbf{f}$, if the alkyl chains adopt anti conformer. Torres and coworkers reported that dodecafluorosubphthalocyanine with a B-F bond formed a onedimensional column in the crystal, where the $\mathrm{B}-\mathrm{B}$ distance, i.e., the stacking distance, was $4.5 \AA^{28}$

Table 8 Powder $\mathrm{X}$-ray diffraction peaks of $2 \mathrm{e}, d$-spacings and Miller indices $(h k l)$ based on the hexagonal lattice with $a=37.3 \pm 0.3 \AA$ and $c$ $=4.8 \pm 0.3 \AA$

\begin{tabular}{lrllll}
\hline $2 \theta(\mathrm{deg})$ & $d(\AA)$ & $(h k l)$ & $2 \theta(\mathrm{deg})$ & $d(\AA)$ & $(h k l)$ \\
\hline 2.70 & 32.65 & $(100)$ & 13.02 & 6.79 & $(410)$ \\
4.84 & 18.24 & $(110)$ & 18.41 & 4.82 & $(001)$ \\
7.52 & 11.75 & $(210)$ & 29.45 & 3.03 & $(721)$ \\
7.83 & 11.28 & $(300)$ & 31.69 & 2.82 & $(821)$ \\
10.13 & 8.73 & $(310)$ & 42.62 & 2.12 & $(622)$ \\
12.22 & 7.23 & $(320)$ & & &
\end{tabular}


Table 9 Powder X-ray diffraction peaks of $2 \mathrm{f}, d$-spacings, and Miller indices $(h k l)$ based on the hexagonal lattice with $a=35.1 \pm 0.2 \AA$ and $c$ $=4.7 \pm 0.7 \AA$

\begin{tabular}{llllll}
\hline $2 \theta(\mathrm{deg})$ & $d(\AA)$ & $(h k l)$ & $2 \theta(\mathrm{deg})$ & $d(\AA)$ & $(h k l)$ \\
\hline 2.90 & 30.45 & $(100)$ & 10.51 & 8.41 & $(310)$ \\
5.10 & 17.31 & $(110)$ & 12.98 & 6.81 & $(320)$ \\
5.78 & 15.28 & $(200)$ & 28.34 & 3.15 & $(621)$ \\
7.81 & 11.31 & $(210)$ & 31.70 & 2.82 & $(551)$ \\
8.26 & 10.70 & $(300)$ & & &
\end{tabular}

Fig. 8 shows XRD patterns of films of $2 \mathbf{e}$ and $2 \mathrm{f}$ at $25^{\circ} \mathrm{C}$ and $180^{\circ} \mathrm{C}$. Diffraction peaks owing to two dimensional hexagonal lattice $(h k 0)$ appeared at $180^{\circ} \mathrm{C}$, indicating that the films retain the hexagonal columnar structure at $180{ }^{\circ} \mathrm{C}$. The diffraction peaks in the range $28-32^{\circ}$ due to the stacking ordering along the $c$-axis direction disappeared at $180^{\circ} \mathrm{C}$. Combined with the POM observations described above, $2 \mathbf{e}$ and $\mathbf{2 f}$ were in a discotic hexagonal columnar mesophase at $180^{\circ} \mathrm{C}$.

\section{Molecular orbital calculations of the stacked dimer of 1c and 2c}

The energy of stacked dimers of $1 \mathbf{c}$ and $2 \mathrm{c}$ relative to monomeric 1c and 2c was calculated at the B3LYP/6-31G(D) level with a fixed
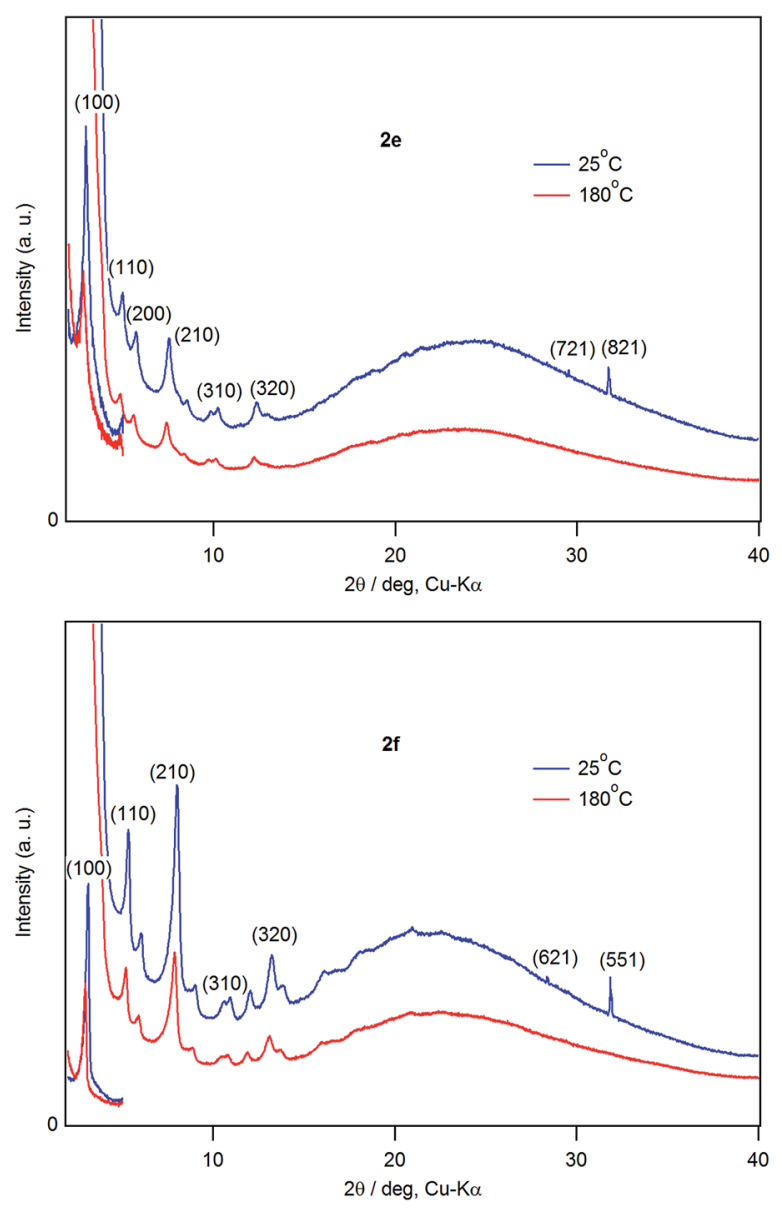

Fig. 8 Variable-temperature XRD of $2 \mathrm{e}$ and $2 \mathrm{f}$.

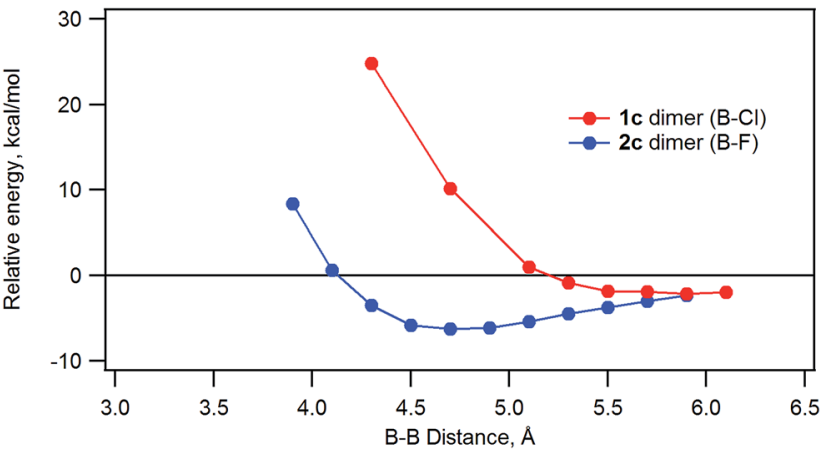

Fig. 9 Plot of the relative energy of dimeric $1 c$ or $2 c$ against the $B-B$ distance calculated by ab initio B3LYP/6-31G(D).
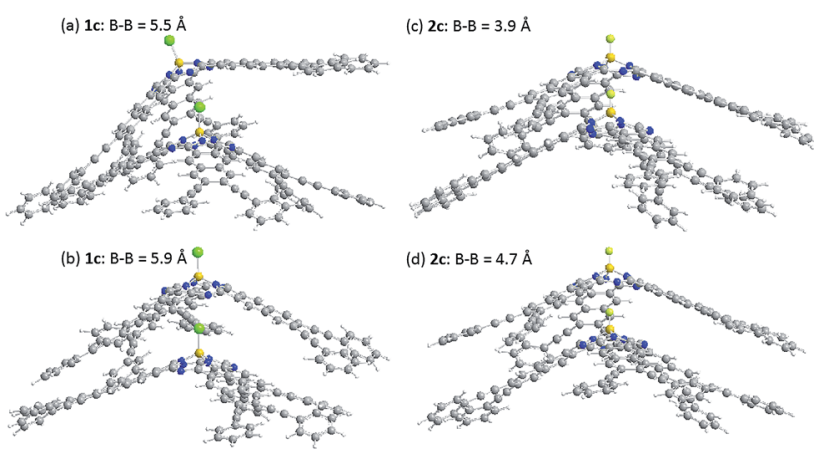

Fig. 10 Optimized structures of dimeric subnaphthalocyanines $1 \mathrm{c}$ and 2c. (a) 1c, B-B distance of $5.5 \AA$, (b) 1c, B-B distance of $5.9 \AA$, (c) 2c, $\mathrm{B}-\mathrm{B}$ distance of $3.9 \AA$, and (d) $2 \mathrm{C}, \mathrm{B}-\mathrm{B}$ distance of $4.7 \AA$.

distance between the two $\mathrm{B}$ atoms of the dimer. The energies were plotted against the B-B distance in Fig. 9. The energy of the dimeric $\mathrm{B}-\mathrm{Cl}$ derivative $1 \mathrm{c}$ decreased as the $\mathrm{B}-\mathrm{B}$ distance was longer, while the energy of the dimeric B-F derivative $2 \mathrm{c}$ showed a minimum at about $4.7 \AA$ of the B-B distance. The geometry optimized structures are shown in Fig. 10. At the B-B distance of $5.5 \AA$, the dimeric 1c showed a bent structure due to a large van der Waals radius of $\mathrm{Cl}$, while the dimeric 2c showed a linear structure even at a B-B distance of $3.9 \AA$. The van der Waals radii of $\mathrm{B}^{29} \mathrm{C}, \mathrm{F}$, and $\mathrm{Cl}^{30}$ are $1.92,1.7,1.47$, and $1.75 \AA$. Therefore, sum of the van der Waals radii, $\mathrm{B}+\mathrm{F}$, are shorter than that of $\mathrm{C}+$ $\mathrm{C}$, while sum of the van der Waals radii, $\mathrm{B}+\mathrm{Cl}$, are larger than that of $\mathrm{C}+\mathrm{C}$. These molecular modelling studies indicate that the smaller van der Waals radius of $\mathrm{F}$ atom can fit to the cleft of cone-shaped subnaphthalocyanine and lead to a stable stacked structure.

\section{Experimental}

${ }^{1} \mathrm{H}$ and ${ }^{13} \mathrm{C}$ nuclear magnetic resonance (NMR) spectra were recorded on a JEOL JNM-ECX DELTA spectrometer using tetramethylsilane as an internal reference (0 ppm). Matrix-assisted laser desorption/ionization time-of-flight (MALDI-TOF) mass spectra were obtained with a Brucker Autoflex Speed mass spectrometer. High resolution FAB MS spectra were recorded 
with a JEOL JMS-700 MStation. Gel-permeation HPLC was performed with a Shimadzu liquid chromatography LC-6AD using Tosoh TSKgel G2000H as a stationary phase and chloroform as eluant. Powder X-ray diffraction was recorded with a Rigaku SmartLab diffractometer with $\mathrm{Cu}-\mathrm{K} \alpha$ radiation. The low angle region, $2 \theta$ of 2 to $5^{\circ}$, was recorded with the $0 \mathrm{D}$ detector, while the wide angle region, $2 \theta$ of 3 to $40^{\circ}$, was recorded with the $1 \mathrm{D}$ silicon strip detector. Variable temperature XRD was recorded for a thin film of subnaphthalocyanines on silicate glass placed in a thermostated Pt holder. Melting points were determined by observing changes in the sample sandwiched between two glasses heated at a rate of $2{ }^{\circ} \mathrm{C}$ min on Mettler-Toredo FP82HT hot stage with a polarized optical microscope Nikon Eclipse LV100 POL. Molecular orbital calculations were performed with Gaussian $09 .{ }^{31}$

\section{Synthesis of subnaphthalocyanines}

1a. In a $100 \mathrm{~mL}$ three-necked flask were placed $3(68 \mathrm{mg}$, $0.051 \mathrm{mmol}$ ), copper iodide (10 mg, $0.053 \mathrm{mmol}), \mathrm{Pd}\left(\mathrm{PPh}_{3}\right)_{4}$ (30 mg, $0.026 \mathrm{mmol})$, dry toluene $(30 \mathrm{~mL})$, and triethylamine (5.0 mL). 1-Hexyne $(1.43 \mathrm{~g}, 17.4 \mathrm{mmol})$ was added and the mixture was stirred at $40{ }^{\circ} \mathrm{C}$ under $\mathrm{Ar}$ for $20 \mathrm{~h}$. The reaction was quenched by the addition of water and the organic layer was separated. The aqueous layer was washed with dichloromethane three times and the dichloromethane solution was combined with the organic layer. The organic solvent was evaporated and the residue was subjected to silica gel column chromatography using toluene to obtain $3.8 \mathrm{mg}$ (7\%) of $\mathbf{1 a}$.

${ }^{1} \mathrm{H}-\mathrm{NMR}\left(\mathrm{CDCl}_{3}, 500 \mathrm{MHz}\right): \delta(\mathrm{ppm})=9.25(\mathrm{~s}, 6 \mathrm{H}), 8.36(\mathrm{~s}$, $6 \mathrm{H}), 2.58(\mathrm{t}, 12 \mathrm{H}), 1.76-1.66(\mathrm{~m}, 12 \mathrm{H}), 1.65-1.57(\mathrm{~m}, 12 \mathrm{H}), 1.02$ $(\mathrm{t}, 18 \mathrm{H}) .{ }^{13} \mathrm{C}-\mathrm{NMR}\left(\mathrm{CDCl}_{3}, 125 \mathrm{MHz}\right): \delta$ (ppm) 148.74, 132.97, 131.94, 128.88, 124.98, 121.64, 95.97, 79.61, 30.87, 22.11, 19.57, 13.77. MALDI-TOF mass: $m / z=1061.3\left[(\mathrm{M}+\mathrm{H})^{+}\right]$, calcd for $\mathrm{C}_{72} \mathrm{H}_{67} \mathrm{BN}_{6} \mathrm{Cl} m / z=1061.5$. HRMS (FAB): $m / z=1060.5144$, calcd for ${ }^{12} \mathrm{C}_{72}{ }^{1} \mathrm{H}_{66}{ }^{14} \mathrm{~N}_{6}{ }^{35} \mathrm{Cl}{ }^{11} \mathrm{~B} \mathrm{~m} / \mathrm{z}=1060.5131$. Visible (dichloromethane) $\lambda_{\text {max }} / \mathrm{nm}(\log \varepsilon): 675$ (5.05).

1b. In a $100 \mathrm{~mL}$ three-necked flask were placed $3(68 \mathrm{mg}$, $0.051 \mathrm{mmol})$, copper iodide (10 $\mathrm{mg}, 0.053 \mathrm{mmol}), \mathrm{Pd}\left(\mathrm{PPh}_{3}\right)_{4}$ (30 $\mathrm{mg}, 0.026 \mathrm{mmol})$, dry toluene $(30 \mathrm{~mL})$, and triethylamine $(5.0 \mathrm{~mL}) .1$-Tetradecyne $(800 \mathrm{mg}, 4.12 \mathrm{mmol})$ was added and the mixture was stirred at $40{ }^{\circ} \mathrm{C}$ under Ar for $20 \mathrm{~h}$. The reaction was quenched by the addition of water and the organic layer was separated. The aqueous layer was washed with dichloromethane three times and the dichloromethane solution was combined with the organic layer. The organic solvent was evaporated and the residue was subjected to silica gel column chromatography using toluene to obtain $5.3 \mathrm{mg}(6 \%)$ of $\mathbf{1 b}$.

${ }^{1} \mathrm{H}-\mathrm{NMR}\left(\mathrm{CDCl}_{3}, 500 \mathrm{MHz}\right): \delta(\mathrm{ppm})=9.26(\mathrm{~s}, 6 \mathrm{H}), 8.35(\mathrm{~s}$, $6 \mathrm{H}), 2.57(\mathrm{t}, 12 \mathrm{H}), 1.74-1.70(\mathrm{~m}, 12 \mathrm{H}), 1.42-1.22(\mathrm{~m}, 108 \mathrm{H}), 0.88$ $(\mathrm{t}, 18 \mathrm{H}) .{ }^{13} \mathrm{C}-\mathrm{NMR}\left(\mathrm{CDCl}_{3}, 125 \mathrm{MHz}\right): \delta$ (ppm) 148.86, 132.94, 131.96, 128.93, 125.05, 121.66, 96.11, 79.57, 31.95, 29.75, 29.71, 29.66, 29.40, 29.35, 29.10, 28.87, 22.71, 19.91, 14.14. MALDITOF mass: $m / z=1734.4\left[(\mathrm{M}+\mathrm{H})^{+}\right]$, calcd for $\mathrm{C}_{120} \mathrm{H}_{163} \mathrm{BN}_{6} \mathrm{Cl}$ $m / z=1734.3$. Visible (dichloromethane) $\lambda_{\max } / \mathrm{nm}(\log \varepsilon): 678$ (5.04).

1c. In a $100 \mathrm{~mL}$ three-necked flask were placed 3 (68 mg, $0.051 \mathrm{mmol})$, copper iodide (10 mg, $0.053 \mathrm{mmol}), \mathrm{Pd}\left(\mathrm{PPh}_{3}\right)_{4}$
(30 mg, $0.026 \mathrm{mmol})$, dry toluene $(30 \mathrm{~mL})$, and triethylamine $(5.0 \mathrm{~mL})$. Ethynylbenzene $(310 \mathrm{mg}, 3.03 \mathrm{mmol})$ was added and the mixture was stirred at $40{ }^{\circ} \mathrm{C}$ under Ar for $20 \mathrm{~h}$. The reaction was quenched by the addition of water and the organic layer was separated. The aqueous layer was washed with dichloromethane three times and the dichloromethane solution was combined with the organic layer. The organic solvent was evaporated and the residue was subjected to silica gel column chromatography using toluene to obtain $4.8 \mathrm{mg}$ (8\%) of 1c.

${ }^{1} \mathrm{H}-\mathrm{NMR}\left(\mathrm{CDCl}_{3}, 500 \mathrm{MHz}\right): \delta(\mathrm{ppm})=9.25(\mathrm{~s}, 6 \mathrm{H}), 8.51(\mathrm{~s}$, $6 \mathrm{H})$, 7.73-7.60 (m, 12H), 7.45-7.33 (m, 18H). MALDI-TOF mass: $m / z=1181.2\left[(\mathrm{M}+\mathrm{H})^{+}\right]$, calcd for $\mathrm{C}_{84} \mathrm{H}_{43} \mathrm{BN}_{6} \mathrm{Cl} m / z=1181.3$. HRMS (FAB): $m / z=1180.3259$, calcd for ${ }^{12} \mathrm{C}_{84}{ }^{1} \mathrm{H}_{42}{ }^{14} \mathrm{~N}_{6}{ }^{35} \mathrm{Cl}^{11} \mathrm{~B}$ $m / z=1180.3253$. Visible (dichloromethane) $\lambda_{\max } / \mathrm{nm}(\log \varepsilon): 682$ (5.05).

1d. In a $100 \mathrm{~mL}$ three-necked flask were placed $3(68 \mathrm{mg}$, $0.051 \mathrm{mmol}$ ), copper iodide (10 mg, $0.053 \mathrm{mmol}), \mathrm{Pd}\left(\mathrm{PPh}_{3}\right)_{4}$ (30 mg, $0.026 \mathrm{mmol})$, dry toluene $(30 \mathrm{~mL})$, and triethylamine (5.0 mL). 1-Ethynyl-3-propylbenzene (440 mg, $3.05 \mathrm{mmol}$ ) was added and the mixture was stirred at $40{ }^{\circ} \mathrm{C}$ under Ar for $20 \mathrm{~h}$. The reaction was quenched by the addition of water and the organic layer was separated. The aqueous layer was washed with dichloromethane three times and the dichloromethane solution was combined with the organic layer. The organic solvent was evaporated and subjected to silica gel column chromatography using toluene to obtain $5.8 \mathrm{mg}(8 \%)$ of $\mathbf{1 d}$.

${ }^{1} \mathrm{H}-\mathrm{NMR}\left(\mathrm{CDCl}_{3}, 500 \mathrm{MHz}\right): \delta(\mathrm{ppm})=9.25(\mathrm{~s}, 6 \mathrm{H}), 8.49(\mathrm{~s}$, $6 \mathrm{H}), 7.58$ (d, 12H, $5 \mathrm{~Hz}), 7.21$ (d, 12H, $5 \mathrm{~Hz}), 2.64(\mathrm{t}, 12 \mathrm{H}), 1.72-$ $1.65(\mathrm{~m}, 12 \mathrm{H}), 0.98(\mathrm{t}, 18 \mathrm{H})$. MALDI-TOF mass: $\mathrm{m} / \mathrm{z}=1432.8$ $\left[\mathrm{M}^{+}\right]$, calcd for $\mathrm{C}_{102} \mathrm{H}_{78} \mathrm{BN}_{6} \mathrm{Cl} m / z=1432.6$. Visible (dichloromethane) $\lambda_{\max } / \mathrm{nm}(\log \varepsilon): 685$ (5.06).

1e. In a $100 \mathrm{~mL}$ three-necked flask were placed 3 (68 mg, $0.051 \mathrm{mmol})$, copper iodide (10 $\mathrm{mg}, 0.053 \mathrm{mmol}), \mathrm{Pd}\left(\mathrm{PPh}_{3}\right)_{4}$ (30 mg, $0.026 \mathrm{mmol})$, dry toluene $(30 \mathrm{~mL})$, and triethylamine (5.0 mL). p-Ethynylhexylbenzene (570 $\mathrm{mg}, 3.06 \mathrm{mmol}$ ) was added and the mixture was stirred at $40{ }^{\circ} \mathrm{C}$ under Ar for $20 \mathrm{~h}$. The reaction was quenched by the addition of water and the organic layer was separated. The aqueous layer was washed with dichloromethane three times and the dichloromethane solution was combined with the organic layer. The organic solvent was evaporated and the residue was subjected to silica gel column chromatography using toluene to obtain $5.1 \mathrm{mg}$ (6\%) of $1 e$.

${ }^{1} \mathrm{H}-\mathrm{NMR}\left(\mathrm{CDCl}_{3}, 500 \mathrm{MHz}\right): \delta(\mathrm{ppm})=9.26(\mathrm{~s}, 6 \mathrm{H}), 8.50(\mathrm{~s}$, $6 \mathrm{H}), 7.58$ (d, 12H, $5 \mathrm{~Hz}), 7.21(\mathrm{~d}, 12 \mathrm{H}, 5 \mathrm{~Hz}), 2.66(\mathrm{t}, 12 \mathrm{H}), 1.66-$ $1.62(\mathrm{~m}, 12 \mathrm{H}), 1.40-1.29(\mathrm{~m}, 36 \mathrm{H}), 0.91(\mathrm{t}, 18 \mathrm{H})$. MALDI-TOF mass: $m / z=1686.1\left[(\mathrm{M}+\mathrm{H})^{+}\right]$, calcd for $\mathrm{C}_{120} \mathrm{H}_{115} \mathrm{BN}_{6} \mathrm{Cl} m / z=$ 1685.9. Visible (dichloromethane) $\lambda_{\max } / \mathrm{nm}(\log \varepsilon): 685$ (5.06).

1f. In a $100 \mathrm{~mL}$ three-necked flask were placed $3(68 \mathrm{mg}$, $0.051 \mathrm{mmol})$, copper iodide (10 $\mathrm{mg}, 0.053 \mathrm{mmol}), \mathrm{Pd}\left(\mathrm{PPh}_{3}\right)_{4}$ (30 mg, $0.026 \mathrm{mmol})$, dry toluene $(30 \mathrm{~mL})$, and triethylamine (5.0 mL). p-Ethynyl(hexyloxy)benzene (620 mg, $3.06 \mathrm{mmol}$ ) was added and the mixture was stirred at $40{ }^{\circ} \mathrm{C}$ under Ar for $20 \mathrm{~h}$. The reaction was quenched by the addition of water and the organic layer was separated. The aqueous layer was washed with dichloromethane three times and the dichloromethane solution was combined with the organic layer. The organic solvent 
was evaporated and the residue was subjected to silica gel column chromatography using toluene to obtain $2.7 \mathrm{mg}$ (3\%) of 1f.

${ }^{1} \mathrm{H}-\mathrm{NMR}\left(\mathrm{CDCl}_{3}, 500 \mathrm{MHz}\right): \delta(\mathrm{ppm})=9.29(\mathrm{~s}, 6 \mathrm{H}), 8.49(\mathrm{~s}$, $6 \mathrm{H}), 7.59$ (d, 12H, $10 \mathrm{~Hz}), 6.92(\mathrm{~d}, 12 \mathrm{H}, 10 \mathrm{~Hz}), 4.01(\mathrm{t}, 12 \mathrm{H})$, 1.84-1.79 (m, 12H), 1.51-1.47 (m, 12H), 1.42-1.32 (m, 24H), 0.93 $(\mathrm{t}, 18 \mathrm{H})$. MALDI-TOF mass: $\mathrm{m} / z=1781.1\left[\mathrm{M}^{+}\right]$, calcd for $\mathrm{C}_{120^{-}}$ $\mathrm{H}_{114} \mathrm{BN}_{6} \mathrm{O}_{6} \mathrm{Cl} m / z=1780.9$. Visible (dichloromethane) $\lambda_{\max } / \mathrm{nm}$ $(\log \varepsilon)$ : 683 (5.04).

2a. In a $100 \mathrm{~mL}$ three-necked flask were placed $4(68 \mathrm{mg}$, $0.052 \mathrm{mmol})$, copper iodide (10 $\mathrm{mg}, 0.053 \mathrm{mmol}), \mathrm{Pd}\left(\mathrm{PPh}_{3}\right)_{4}$ (30 mg, $0.026 \mathrm{mmol})$, dry dimethylsulfoxide $(30 \mathrm{~mL})$, and triethylamine $(5.0 \mathrm{~mL})$. 1-Hexyne $(1.40 \mathrm{~g}, 17.0 \mathrm{mmol})$ was added and the mixture was stirred at $40{ }^{\circ} \mathrm{C}$ under Ar for $20 \mathrm{~h}$. The reaction was quenched by the addition of water. This solution was washed with dichloromethane three times. The organic solvent was evaporated and the residual oil containing a small amount of DMSO was subjected to silica gel column chromatography using toluene to obtain $10.1 \mathrm{mg}$ (19\%) of $2 \mathrm{a}$.

${ }^{1} \mathrm{H}-\mathrm{NMR}\left(\mathrm{CDCl}_{3}, 500 \mathrm{MHz}\right): \delta(\mathrm{ppm})=9.22(\mathrm{~s}, 6 \mathrm{H}), 8.34(\mathrm{~s}$, $6 \mathrm{H}), 2.58(\mathrm{t}, 12 \mathrm{H}), 1.73-1.68(\mathrm{~m}, 12 \mathrm{H}), 1.63-1.58(\mathrm{~m}, 12 \mathrm{H}), 1.01$ $(\mathrm{t}, 18 \mathrm{H})$. MALDI-TOF mass: $m / z=1044.7\left[\mathrm{M}^{+}\right]$, calcd for $\mathrm{C}_{72} \mathrm{H}_{66} \mathrm{BN}_{6} \mathrm{~F} m / z=1044.5$. HRMS (FAB): $m / z=1044.5413$, calcd for ${ }^{12} \mathrm{C}_{72}{ }^{1} \mathrm{H}_{66}{ }^{14} \mathrm{~N}_{6}{ }^{19} \mathrm{~F}{ }^{11} \mathrm{~B} \mathrm{~m} / z=1044.5426$. Visible (dichloromethane) $\lambda_{\max } / \mathrm{nm}(\log \varepsilon): 669$ (5.05).

2b. In a $100 \mathrm{~mL}$ three-necked flask were placed 4 (68 mg, $0.052 \mathrm{mmol})$, copper iodide (10 $\mathrm{mg}, 0.053 \mathrm{mmol}), \mathrm{Pd}\left(\mathrm{PPh}_{3}\right)_{4}$ (30 mg, $0.026 \mathrm{mmol}$ ), and dry dimethylsulfoxide $(30 \mathrm{~mL})$, and triethylamine $(5.0 \mathrm{~mL})$. 1-Tetradecyne $(600 \mathrm{mg}, 3.08 \mathrm{mmol})$ was added and the mixture was stirred at $40{ }^{\circ} \mathrm{C}$ under Ar for $20 \mathrm{~h}$. The reaction was quenched by the addition of water. This solution was washed with dichloromethane three times. The organic solvent was evaporated and the residue was subjected to silica gel column chromatography using toluene to obtain $14.0 \mathrm{mg}(16 \%)$ of $\mathbf{2 b}$.

${ }^{1} \mathrm{H}-\mathrm{NMR}\left(\mathrm{CDCl}_{3}, 500 \mathrm{MHz}\right): \delta(\mathrm{ppm})=9.21(\mathrm{~s}, 6 \mathrm{H}), 8.33(\mathrm{~s}$, $6 \mathrm{H}), 2.57(\mathrm{t}, 12 \mathrm{H}), 1.75-1.69(\mathrm{~m}, 12 \mathrm{H}), 1.42-1.25(\mathrm{~m}, 108 \mathrm{H}), 0.87$ $(\mathrm{t}, 18 \mathrm{H})$. MALDI-TOF mass: $m / z=1717.5\left[\mathrm{M}^{+}\right]$, calcd for $\mathrm{C}_{120} \mathrm{H}_{162} \mathrm{BN}_{6} \mathrm{~F} / z=1717.3$. Visible (dichloromethane) $\lambda_{\max } / \mathrm{nm}$ $(\log \varepsilon): 671$ (5.04).

2c. In a $100 \mathrm{~mL}$ three-necked flask were placed 4 (68 mg, $0.052 \mathrm{mmol})$, copper iodide (10 mg, $0.053 \mathrm{mmol}), \mathrm{Pd}\left(\mathrm{PPh}_{3}\right)_{4}$ (30 mg, $0.026 \mathrm{mmol})$, and dry dimethylsulfoxide $(30 \mathrm{~mL})$, and triethylamine $(5.0 \mathrm{~mL})$. Ethynylbenzene $(310 \mathrm{mg}, 3.03 \mathrm{mmol})$ was added and the mixture was stirred at $40{ }^{\circ} \mathrm{C}$ under $\mathrm{Ar}$ for $20 \mathrm{~h}$. Then, hexane is added to the reaction solution, the mixture is filtered, and then a solvent in the filtered solution is removed. The obtained solid was washed with hexane, methanol, acetone, dichloromethane, chloroform, ethyl acetate, $28 \%$ aqueous ammonia, and diethyl ether to obtain $2 \mathrm{c}: 5.9 \mathrm{mg}, 10 \%$ yield.

MALDI-TOF mass: $m / z=1164.3\left[\mathrm{M}^{+}\right]$, calcd for $\mathrm{C}_{84} \mathrm{H}_{42} \mathrm{BN}_{6} \mathrm{~F}$ $m / z=1164.4$. Visible (dichloromethane) $\lambda_{\max } / \mathrm{nm}(\log \varepsilon): 677$ (5.01).

2d. In a $100 \mathrm{~mL}$ three-necked flask were placed 4 (68 $\mathrm{mg}$, $0.052 \mathrm{mmol})$, copper iodide (10 $\mathrm{mg}, 0.053 \mathrm{mmol}), \mathrm{Pd}\left(\mathrm{PPh}_{3}\right)_{4}$ (30 mg, $0.026 \mathrm{mmol})$, and dry dimethylsulfoxide $(30 \mathrm{~mL})$, and triethylamine (5.0 mL). p-Propylphenylacetylene (440 mg, 3.05 $\mathrm{mmol}$ ) was added and the mixture was stirred at $40{ }^{\circ} \mathrm{C}$ under $\mathrm{Ar}$ for $20 \mathrm{~h}$. The reaction solution was subjected to silica gel column chromatography using toluene and evaporated in vacuo. The obtained solid was washed with hexane and recrystallized from chloroform to obtain $14.4 \mathrm{mg}$ (20\%) of $\mathbf{2 d}$.

${ }^{1} \mathrm{H}-\mathrm{NMR}\left(\mathrm{CDCl}_{3}, 500 \mathrm{MHz}\right): \delta(\mathrm{ppm})=9.11(\mathrm{~s}, 6 \mathrm{H}), 8.42(\mathrm{~s}$, $6 \mathrm{H}), 7.54(\mathrm{~d}, 12 \mathrm{H}, 5 \mathrm{~Hz}), 7.15(\mathrm{~m}, 12 \mathrm{H}, 10 \mathrm{~Hz}), 2.62(\mathrm{t}, 12 \mathrm{H})$, 1.69-1.64 (m, 12H), $0.98(\mathrm{t}, 18 \mathrm{H})$. MALDI-TOF mass: $\mathrm{m} / \mathrm{z}=$ 1416.6 $\left[\mathrm{M}^{+}\right]$, calcd for $\mathrm{C}_{102} \mathrm{H}_{78} \mathrm{BN}_{6} \mathrm{~F} \mathrm{~m} / z=1416.6$. Visible (dichloromethane) $\lambda_{\max } / \mathrm{nm}(\log \varepsilon): 678$ (5.06).

2e. In a $100 \mathrm{~mL}$ three-necked flask were placed 4 (68 mg, $0.052 \mathrm{mmol}$ ), copper iodide (10 mg, $0.053 \mathrm{mmol}), \mathrm{Pd}\left(\mathrm{PPh}_{3}\right)_{4}$ (30 mg, $0.026 \mathrm{mmol}$ ), and dry dimethylsulfoxide $(30 \mathrm{~mL})$, and triethylamine $(5.0 \mathrm{~mL})$. $p$-Ethynylhexylbenzene $(570 \mathrm{mg}, 3.06$ $\mathrm{mmol}$ ) was added and the mixture was stirred at $40{ }^{\circ} \mathrm{C}$ under $\mathrm{Ar}$ for $20 \mathrm{~h}$. The reaction was quenched by the addition of water. This solution was washed with dichloromethane three times. The organic solvent was evaporated and the residue was subjected to silica gel column chromatography using toluene to obtain $18.7 \mathrm{mg}(22 \%)$ of 2 e.

${ }^{1} \mathrm{H}-\mathrm{NMR}\left(\mathrm{CDCl}_{3}, 500 \mathrm{MHz}\right): \delta(\mathrm{ppm})=9.04(\mathrm{~s}, 6 \mathrm{H}), 8.39(\mathrm{~s}$, $6 \mathrm{H}), 7.53(\mathrm{~d}, 12 \mathrm{H}, 10 \mathrm{~Hz}), 7.11(\mathrm{~d}, 12 \mathrm{H}, 5 \mathrm{~Hz}), 2.63(\mathrm{t}, 12 \mathrm{H}), 1.65-$ $1.61(\mathrm{~m}, 12 \mathrm{H}), 1.42-1.25(\mathrm{~m}, 36 \mathrm{H}), 0.92(\mathrm{t}, 18 \mathrm{H})$. MALDI-TOF mass: $m / z=1668.9\left[\mathrm{M}^{+}\right]$, calcd for $\mathrm{C}_{120} \mathrm{H}_{114} \mathrm{BN}_{6} \mathrm{~F} \mathrm{~m} / z=$ 1668.9. Visible (dichloromethane) $\lambda_{\max } / \mathrm{nm}(\log \varepsilon): 678$ (5.06).

2f. In a $100 \mathrm{~mL}$ three-necked flask were placed 4 (68 mg, $0.052 \mathrm{mmol}$ ), copper iodide (10 $\mathrm{mg}, 0.053 \mathrm{mmol}), \mathrm{Pd}\left(\mathrm{PPh}_{3}\right)_{4}$ (30 mg, $0.026 \mathrm{mmol}$ ), and dry dimethylsulfoxide $(30 \mathrm{~mL}$ ), and triethylamine $(5.0 \mathrm{~mL})$. p-Ethynyl(hexyloxy)benzene $(620 \mathrm{mg}$, $3.06 \mathrm{mmol}$ ) was added and the mixture was stirred at $40{ }^{\circ} \mathrm{C}$ under Ar for $20 \mathrm{~h}$. The reaction was quenched by the addition of water. This solution was washed with dichloromethane three times. The organic solvent was evaporated and the residue was subjected to silica gel column chromatography using toluene to obtain $24.3 \mathrm{mg}(27 \%)$ of $2 \mathbf{f}$.

${ }^{1} \mathrm{H}-\mathrm{NMR}\left(\mathrm{CDCl}_{3}, 500 \mathrm{MHz}\right): \delta(\mathrm{ppm})=8.88(\mathrm{~s}, 6 \mathrm{H}), 8.28(\mathrm{~s}$, $6 \mathrm{H}), 7.51(\mathrm{~d}, 12 \mathrm{H}, 10 \mathrm{~Hz}), 6.81(\mathrm{~d}, 12 \mathrm{H}, 10 \mathrm{~Hz}), 3.95(\mathrm{t}, 12 \mathrm{H})$, 1.85-1.78 (m, 12H), 1.53-1.45 (m, 12H), 1.43-1.30 (m, 24H), 0.95 $(\mathrm{t}, 18 \mathrm{H})$. MALDI-TOF mass: $m / z=1765.0\left[\mathrm{M}^{+}\right]$, calcd for $\mathrm{C}_{120} \mathrm{H}_{114} \mathrm{BN}_{6} \mathrm{O}_{6} \mathrm{~F} m / z=1764.9$. Visible (dichloromethane) $\lambda_{\max } /$ $\mathrm{nm}(\log \varepsilon): 681$ (5.05).

2g. In a $100 \mathrm{~mL}$ three-necked flask were placed 4 (68 $\mathrm{mg}$, $0.052 \mathrm{mmol}$ ), copper iodide (10 $\mathrm{mg}, 0.053 \mathrm{mmol}), \mathrm{Pd}\left(\mathrm{PPh}_{3}\right)_{4}$ (30 mg, $0.026 \mathrm{mmol}$ ), and dry dimethylsulfoxide $(30 \mathrm{~mL})$, and triethylamine $(5.0 \mathrm{~mL})$. 5-Ethynyl-1,2,3-tris(hexyloxy)benzene $(1.23 \mathrm{~g}, 3.05 \mathrm{mmol})$ was added and the mixture was stirred at $40{ }^{\circ} \mathrm{C}$ under $\mathrm{Ar}$ for $20 \mathrm{~h}$. The reaction was quenched by the addition of water. This solution was washed with dichloromethane three times. The organic solvent was evaporated and the residue was subjected to silica gel column chromatography using toluene to obtain $15.1 \mathrm{mg}(10 \%)$ of $2 \mathrm{~g}$.

${ }^{1} \mathrm{H}-\mathrm{NMR}\left(\mathrm{CDCl}_{3}, 500 \mathrm{MHz}\right): \delta(\mathrm{ppm})=9.33(\mathrm{~s}, 6 \mathrm{H}), 8.51(\mathrm{~s}$, $6 \mathrm{H}), 6.58(\mathrm{~s}, 12 \mathrm{H}), 3.98(\mathrm{t}, 12 \mathrm{H}), 3.89(\mathrm{t}, 24 \mathrm{H}), 1.82-1.68(\mathrm{~m}$, $36 \mathrm{H}), 1.53-1.40(\mathrm{~m}, 36 \mathrm{H}), 1.39-1.27(\mathrm{~m}, 72 \mathrm{H}), 0.97-0.80(\mathrm{~m}$, 54H). ${ }^{13} \mathrm{C}-\mathrm{NMR}\left(\mathrm{CDCl}_{3}, 125 \mathrm{MHz}\right): \delta(\mathrm{ppm})$ 153.14, 150.29, 139.54, 132.74, 132.18, 129.34, 124.27, 121.96, 117.28, 110.19, 
$95.67,87.08,73.54,69.10,31.78,31.62,30.33,29.33,25.82$, $25.77,22.71,22.65,14.10,14.05$. MALDI-TOF mass: $\mathrm{m} / \mathrm{z}=$ $2966.0\left[\mathrm{M}^{+}\right]$, calcd for $\mathrm{C}_{192} \mathrm{H}_{258} \mathrm{BN}_{6} \mathrm{O}_{18} \mathrm{~F} \mathrm{~m} / z=2966.0$. Visible (dichloromethane) $\lambda_{\max } / \mathrm{nm}(\log \varepsilon): 678$ (5.06).

5-Bromo-1,2,3-tri(hexyloxy)benzene (13). A $4.9 \mathrm{~g}$ portion of 5bromo-1,2,3-trimethoxybenzene $(20 \mathrm{mmol})$ was dissolved in $100 \mathrm{~mL}$ of dichloromethane, and the solution was cooled to $-78{ }^{\circ} \mathrm{C}$, followed by the slow addition of $60 \mathrm{~mL} \mathrm{BBr}_{3}(1 \mathrm{M}$ in DCM). The mixture was allowed to warm to room temperature over $4 \mathrm{~h}$ and stirred for $60 \mathrm{~h}$. The reaction was quenched by icewater and the mixture was extracted with ethyl acetate $(40 \mathrm{~mL}$ $\times 3$ ). The organic layer was concentrated under reduced pressure to afford $4.3 \mathrm{~g}$ 5-bromo-1,2,3-benzenetriol as a white solid, which was directly submitted to the next reaction. This solid was dissolved in $100 \mathrm{~mL}$ DMF and the solution was degassed by bubbling argon for $15 \mathrm{~min}$, then $24.0 \mathrm{~g} \mathrm{~K}_{2} \mathrm{CO}_{3}(173 \mathrm{mmol}$ ) was added. The mixture was stirred at room temperature for $10 \mathrm{~min}$, and then $12.8 \mathrm{~g}$ 1-bromohexane $(77.3 \mathrm{mmol})$ was added. The mixture was heated to $60{ }^{\circ} \mathrm{C}$ for $4 \mathrm{~h}$. After cooling, the reaction was quenched by the addition of ice-water. This solution was washed with ethyl acetate $(50 \mathrm{~mL} \times 2)$. The organic solvent was evaporated and the residue was subjected to silica gel column chromatography ( $n$-hexane/DCM $=1: 1)$ to obtain $6.2 \mathrm{~g}(65 \%)$ of $\mathbf{1 3}$ as a white powder.

${ }^{1} \mathrm{H}-\mathrm{NMR}\left(\mathrm{CDCl}_{3}, 500 \mathrm{MHz}\right): \delta(\mathrm{ppm})=6.67(\mathrm{~s}, 2 \mathrm{H}), 3.92(\mathrm{~m}$, $6 \mathrm{H}), 1.84-1.67$ (m, 6H), 1.57-1.23 (m, 18H), 0.94-0.85 (m, 9H). MALDI-TOF mass: $m / z=456.2\left[\mathrm{M}^{+}\right]$, calcd for $\mathrm{C}_{24} \mathrm{H}_{41} \mathrm{BrO}_{3} \mathrm{~m} / z=$ 456.2.

1,2,3-Tri(hexyloxy)-5-[2-(trimethylsilyl)ethynyl]benzene (14). In a $100 \mathrm{~mL}$ three-necked flask were placed $13(5.0 \mathrm{~g}, 11 \mathrm{mmol})$, copper iodide (100 mg, $0.53 \mathrm{mmol}), \mathrm{Pd}\left(\mathrm{PPh}_{3}\right)_{4}(1.5 \mathrm{~g}, 1.3 \mathrm{mmol})$, and piperidine $(30 \mathrm{~mL})$. Trimethylsilylacetylene $(1.53 \mathrm{~g}, 15.6$ $\mathrm{mmol}$ ) was added and the mixture was stirred at $80^{\circ} \mathrm{C}$ under $\mathrm{Ar}$ for $12 \mathrm{~h}$. The reaction was quenched by the addition of $20 \mathrm{~mL}$ $2 \mathrm{M}$ aqueous ammonium chloride. The mixture was extracted with diethyl ether $(100 \mathrm{~mL} \times 3)$ and dichloromethane $(100 \mathrm{~mL}$ $\times 2$ ). The organic solvent was evaporated and the residue was subjected to silica gel column chromatography ( $n$-hexane/DCM $=1: 1)$ to obtain $5.1 \mathrm{~g}(98 \%)$ of 14 .

${ }^{1} \mathrm{H}-\mathrm{NMR}\left(\mathrm{CDCl}_{3}, 500 \mathrm{MHz}\right): \delta(\mathrm{ppm})=6.66(\mathrm{~s}, 2 \mathrm{H}), 3.97-3.93$ (m, 6H), 1.81-1.69 (m, 6H), 1.49-1.28 (m, 18H), 0.92-0.87 (m, 9H). MALDI-TOF mass: $m / z=497.4\left[(\mathrm{M}+\mathrm{Na})^{+}\right]$, calcd for $\mathrm{C}_{29^{-}}$ $\mathrm{H}_{50} \mathrm{O}_{3} \mathrm{SiNa} m / z=497.3$.

5-Ethynyl-1,2,3-tri(hexyloxy)benzene (15). Compound 2 $(4.0 \mathrm{~g}, 8.4 \mathrm{mmol})$ was dissolved in $40 \mathrm{~mL}$ dichloromethane and $40 \mathrm{~mL}$ of methanol, and then $3.50 \mathrm{~g}$ potassium carbonate (25.4 $\mathrm{mmol}$ ) was added. The mixture was stirred for $4 \mathrm{~h}$ at room temperature. The reaction was quenched by the addition of $20 \mathrm{~mL}$ water. This solution was washed with DCM $(100 \mathrm{~mL} \times 2)$. The organic layer was concentrated under reduced pressure and the residue was purified by silica gel column chromatography ( $n$-hexane/DCM $=4: 1$ ) to give $2.9 \mathrm{~g}$ of title product $15(86 \%) .{ }^{1} \mathrm{H}$ NMR spectrum was identical to that reported in the literature. ${ }^{32}$

${ }^{1} \mathrm{H}-\mathrm{NMR}\left(\mathrm{CDCl}_{3}, 500 \mathrm{MHz}\right): \delta(\mathrm{ppm})=6.69(\mathrm{~s}, 2 \mathrm{H}), 3.98-3.93$ $(\mathrm{m}, 6 \mathrm{H}), 2.99(\mathrm{~s}, 1 \mathrm{H}), 1.81-1.70(\mathrm{~m}, 6 \mathrm{H}), 1.49-1.30(\mathrm{~m}, 18 \mathrm{H})$, 0.92-0.88 (m, 9H). MALDI-TOF mass: $m / z=425.3\left[(\mathrm{M}+\mathrm{Na})^{+}\right]$, calcd for $\mathrm{C}_{26} \mathrm{H}_{42} \mathrm{O}_{3} \mathrm{Na} m / z=425.3$.

\section{Conclusions}

Chloroboron(III) and fluoroboron(III) hexaethynylsubnaphthalocyanines were prepared by Sonogashira coupling. The B-F derivatives showed higher melting points and lower solubilities than the corresponding $\mathrm{B}-\mathrm{Cl}$ derivatives. $\mathrm{XRD}, \mathrm{POM}$, visible spectroscopic studies indicated that the $\mathrm{B}-\mathrm{F}$ derivatives were packed in the hexagonal columnar structure, while the $\mathrm{B}-\mathrm{Cl}$ derivatives were poorly crystalline. The B-F derivatives with hexylphenyl or hexyloxyphenyl groups showed mesophase at $180{ }^{\circ} \mathrm{C}$. We demonstrated that design of the peripheral substituents and the axial halogen is efficient strategy to control molecular packing of highly polar subnaphthalocyanines.

\section{Conflicts of interest}

There are no conflicts to declare.

\section{Acknowledgements}

We thank Drs Toshinobu Ohno and Yo Shimizu for valuable discussions. We also thank Koji Ohoka for his help in high resolution mass spectroscopic studies.

\section{Notes and references}

1 (a) G. E. Morse and T. P. Bender, ACS Appl. Mater. Interfaces, 2012, 4, 5055; G. de la Torre, G. Bottari and T. Torres, Adv. Energy Mater., 2017, 7, 1601700. (b) K. Cnops, G. Zango, J. Genoe, P. Heremans, M. V. Martinez-Diaz, T. Torres and D. Cheyns, J. Am. Chem. Soc., 2015, 137, 8991.

2 D. Hohnholz, S. Steinbrecher and M. Hanack, J. Mol. Struct., 2000, 521, 231.

3 (a) C. Piechocki, J. Simon, A. Skoulios, D. Guillon and P. Weber, J. Am. Chem. Soc., 1982, 104, 5245; (b) B. A. Gregg, M. A. Fox and A. J. Bard, J. Am. Chem. Soc., 1989, 111, 3024; (c) B. A. Gregg, M. A. Fox and A. J. Bard, J. Phys. Chem., 1990, 94, 1586; (d) P. G. Schouten, J. M. Warman, M. P. de Haas, M. A. Fox and H.-L. Pan, Nature, 1991, 353, 736; (e) K. Hatsusaka, K. Ohta, I. Yamamoto and H. Shirai, J. Mater. Chem., 2001, 11, 423.

4 (a) H. E. Katz, Z. Bao and S. L. Gilat, Acc. Chem. Res., 2001, 34, 359; (b) C. D. Sheraw, T. N. Jackson, D. L. Eaton and J. E. Anthony, Adv. Mater., 2003, 15, 2009; (c) C. R. Newman, C. D. Frisbie, D. A. da Silva Filho, J.-L. Bredas, P. C. Ewbank and K. R. Mann, Chem. Mater., 2004, 16, 4436; (d) S. Sergeyev, W. Pisula and Y. H. Geerts, Chem. Soc. Rev., 2007, 36, 1902; (e) Q. Ye, J. Chang, K.-W. Huang and C. Chi, Org. Lett., 2011, 13, 5960.

5 P. G. Schouten, J. M. Warman, M. P. de Haas, C. F. van Nostrum, G. H. Gelinck, R. J. M. Nolte, M. J. Copyn, J. W. Zwikker, M. K. Engel, M. Hanack, Y. H. Chang and W. T. Ford, J. Am. Chem. Soc., 1994, 116, 6880.

6 H. Kietaibl, Monatsh. Chem., 1974, 105, 405. 
7 C. G. Claessens, D. Gonzalez-Rodriguez, M. S. RodriguezMorgade, A. Medina and T. Torres, Chem. Rev., 2014, 114, 2192.

8 B. Verreet, S. Schols, D. Cheyns, B. P. Rand, H. Gommans, T. Aernouts, P. Heremans and J. Genoe, J. Mater. Chem., 2009, 19, 5295.

9 A. M. van der Craats and J. M. Warman, Adv. Mater., 2001, 13, 130.

10 J. Guilleme, J. Arago, E. Orti, E. Cavero, T. Sierra, J. Ortega, C. L. Folcia, J. Etxebarria, D. Gonzalez-Rodriguez and T. Torres, J. Mater. Chem. C, 2015, 3, 985.

11 (a) K. L. Mutolo, E. I. Mayo, B. P. Rand, S. R. Forrest and M. E. Thompson, J. Am. Chem. Soc., 2006, 128, 8108; (b) H. Gommans, T. Aernouts, B. Verreet, P. Heremans, A. Medina, C. G. Claessens and T. Torres, Adv. Funct. Mater., 2009, 19, 3435; (c) H. Gommans, T. Aernouts, B. Verreet, P. Heremans, A. Medina, C. G. Claessens and T. Torres, Adv. Funct. Mater., 2009, 19, 3435; (d) B. Ma, C. H. Woo, Y. Miyamoto and J. M. J. Frechet, Chem. Mater., 2009, 21, 1413.

12 (a) Y. Takao, T. Masuoka, K. Yamamoto, T. Mizutani, F. Matsumoto, K. Moriwaki, K. Hida, T. Iwai, T. Ito, T. Mizuno and T. Ohno, Tetrahedron Lett., 2014, 55, 4564; (b) K. Yamamoto, A. Takagi, M. Hada, R. Taniwaki, T. Mizutani, Y. Kimura, Y. Takao, K. Moriwaki, F. Matsumoto, T. Ito, T. Iwai, K. Hida, T. Mizuno and T. Ohno, Tetrahedron, 2016, 72, 4918.

13 D. S. Terekhov, K. J. M. Nolan, C. R. McArthur and C. C. Leznoff, J. Org. Chem., 1996, 61, 3034.

14 J. D. Dang, D. S. Josey, A. J. Lough, Y. Li, A. Sifate, Z.-H. Luc and T. P. Bender, J. Mater. Chem. A, 2016, 4, 9566.

15 K. Sonogashira, Y. Tohda and N. Hagihara, Tetrahedron Lett., 1975, 4467.

16 J. Guilleme, D. Gonzalez-Rodriguez and T. Torres, Angew. Chem., Int. Ed., 2011, 50, 3506.

17 D. Velasco, V. Jankauskas, J. Stumbraite, J. V. Grazulevicius and V. Getautis, Synth. Met., 2009, 159, 654.

18 M. V. Fulford, D. Jaidka, A. S. Paton, G. E. Morse, E. R. L. Brisson, A. J. Lough and T. P. Bender, J. Chem. Eng. Data, 2012, 57, 2756.

19 G. Martin, G. Rojo, F. Agullo-Lopez, V. R. Ferro, J. M. G. de la Vega, M. V. Martinez-Diaz, T. Torres, I. Ledoux and J. Zyss, J. Phys. Chem. B, 2002, 106, 13139.

20 M. Kasha, H. R. Rawls, M. Ashraf and A. El-Bayoumi, Pure Appl. Chem., 1965, 11, 371.

21 J. M. Kroon, R. B. M. Koehorst, M. van Dijk, G. M. Sanders and E. J. R. Sudholter, J. Mater. Chem., 1997, 7, 615.

22 C. Colomban, E. V. Kudrik, V. Briois, J. C. Shwarbrick, A. B. Sorokin and P. Afanasiev, Inorg. Chem., 2014, 53, 11517.

23 B. Koksoy, O. Soyer, E. B. Orman, A. R. Ozkaya and M. Bulut, Dyes Pigm., 2015, 118, 166.

24 N. Kobayashi, T. Ishizaki, K. Ishii and H. Konami, J. Am. Chem. Soc., 1999, 121, 9096.

25 S. Nonell, N. Rubio, B. del Rey and T. Torres, J. Chem. Soc., Perkin Trans. 2, 2000, 1091.
26 A. Concellon, M. Marcos, P. Romero, J. L. Serrano, R. Termine and A. Golemme, Angew. Chem., Int. Ed., 2017, 56, 1259.

27 S. H. Kang, Y.-S. Kang, W.-C. Zin, G. Olbrechts, K. Wostyn, K. Clays, A. Persoons and K. Kim, Chem. Commun., 1999, 1661.

28 (a) M. S. Rodriguez-Morgade, C. G. Claessens, A. Medina, D. Gonzalez-Rodriguez, E. Gutierrez-Puebla, A. Monge, I. Alkorta, J. Elguero and T. Torres, Chem.-Eur. J., 2008, 14, 1342; (b) J. Guilleme, M. J. Mayoral, J. Calbo, J. Arago, P. M. Viruela, E. Orti, T. Torres and D. GonzalezRodriguez, Angew. Chem., Int. Ed., 2015, 54, 2543.

29 M. Mantina, A. C. Chamberlin, R. Valero, C. J. Cramer and D. G. Truhlar, J. Phys. Chem. A, 2009, 113, 5806.

30 A. Bondi, J. Phys. Chem., 1964, 68, 441.

31 M. J. Frisch, G. W. Trucks, H. B. Schlegel, G. E. Scuseria, M. A. Robb, J. R. Cheeseman, G. Scalmani, V. Barone, B. Mennucci, G. A. Petersson, H. Nakatsuji, M. Caricato, X. Li, H. P. Hratchian, A. F. Izmaylov, J. Bloino, G. Zheng, J. L. Sonnenberg, M. Hada, M. Ehara, K. Toyota, R. Fukuda, J. Hasegawa, M. Ishida, T. Nakajima, Y. Honda, O. Kitao, H. Nakai, T. Vreven, J. J. A. Montgomery, J. E. Peralta, F. Ogliaro, M. Bearpark, J. J. Heyd, E. Brothers, K. N. Kudin, V. N. Staroverov, R. Kobayashi, J. Normand, K. Raghavachari, A. Rendell, J. C. Burant, S. S. Iyengar, J. Tomasi, M. Cossi, N. Rega, J. M. Millam, M. Klene, J. E. Knox, J. B. Cross, V. Bakken, C. Adamo, J. Jaramillo, R. Gomperts, R. E. Stratmann, O. Yazyev, A. J. Austin, R. Cammi, C. Pomelli, J. W. Ochterski, R. L. Martin, K. Morokuma, V. G. Zakrzewski, G. A. Voth, P. Salvador, J. J. Dannenberg, S. Dapprich, A. D. Daniels, O. Farkas, J. B. Foresman, J. V. Ortiz, J. Cioslowski, and D. J. Fox, in Gaussian 09, Revision A.02, 2009; M. J. Frisch, G. W. Trucks, H. B. Schlegel, G. E. Scuseria, M. A. Robb, J. R. Cheeseman, G. Scalmani, V. Barone, B. Mennucci, G. A. Petersson, H. Nakatsuji, M. Caricato, X. Li, H. P. Hratchian, A. F. Izmaylov, J. Bloino, G. Zheng, J. L. Sonnenberg, M. Hada, M. Ehara, K. Toyota, R. Fukuda, J. Hasegawa, M. Ishida, T. Nakajima, Y. Honda, O. Kitao, H. Nakai, T. Vreven, J. A. Montgomery, J. E. Peralta, F. Ogliaro, M. Bearpark, J. J. Heyd, E. Brothers, K. N. Kudin, V. N. Staroverov, R. Kobayashi, J. Normand, K. Raghavachari, A. Rendell, J. C. Burant, S. S. Iyengar, J. Tomasi, M. Cossi, N. Rega, J. M. Millam, M. Klene, J. E. Knox, J. B. Cross, V. Bakken, C. Adamo, J. Jaramillo, R. Gomperts, R. E. Stratmann, O. Yazyev, A. J. Austin, R. Cammi, C. Pomelli, J. W. Ochterski, R. L. Martin, K. Morokuma, V. G. Zakrzewski, G. A. Voth, P. Salvador, J. J. Dannenberg, S. Dapprich, A. D. Daniels, O. Farkas, J. B. Foresman, J. V. Ortiz, J. Cioslowski and D. J. Fox, Gaussian, Inc., Wallingford CT, 2009.

32 Y. Long, H. Chen, Y. Yang, H. Wang, Y. Yang, N. Li, K. Li, J. Pei and F. Liu, Macromolecules, 2009, 42, 6501. 